\title{
In situ measurements of tropical cloud properties in the West African Monsoon: upper tropospheric ice clouds, Mesoscale Convective System outflow, and subvisual cirrus
}

\author{
W. Frey ${ }^{1}$, S. Borrmann ${ }^{1,2}$, D. Kunkel ${ }^{1}$, R. Weigel ${ }^{2}$, M. de Reus ${ }^{3}$, H. Schlager ${ }^{4}$, A. Roiger ${ }^{4}$, C. Voigt ${ }^{2,4}$, P. Hoor $^{2}$, \\ J. Curtius ${ }^{5}$, M. Krämer ${ }^{6}$, C. Schiller ${ }^{6}$, C. M. Volk ${ }^{7}$, C. D. Homan ${ }^{7}{ }^{*}$, F. Fierli ${ }^{8}$, G. Di Donfrancesco ${ }^{9}$, A. Ulanovsky ${ }^{10}$,

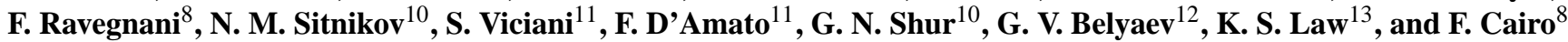 \\ ${ }^{1}$ Max Planck Institute for Chemistry, Particle Chemistry Department, Mainz, Germany \\ ${ }^{2}$ Institute for Atmospheric Physics, Johannes Gutenberg University, Mainz, Germany \\ ${ }^{3}$ Elementar Analysensysteme GmbH, Hanau, Germany \\ ${ }^{4}$ Institut für Physik der Atmosphäre, DLR, Oberpfaffenhofen, Germany \\ ${ }^{5}$ Institute for Atmospheric and Environmental Sciences, Frankfurt University, Frankfurt, Germany \\ ${ }^{6}$ Forschungszentrum Jülich, IEK-7, Jülich, Germany \\ ${ }^{7}$ Department of Physics, University of Wuppertal, Germany \\ ${ }^{8}$ Institute of Atmospheric Science and Climate, ISAC-CNR, Rome, Italy \\ ${ }^{9}$ Ente Nazionale per le Nuove tecnologie, l'Energia e l'Ambiente, Frascati, Italy \\ ${ }^{10}$ Central Aerological Observatory, Dolgoprudny, Moskow Region, Russia \\ ${ }^{11}$ CNR-INO National Institute of Optics, Florence, Italy \\ ${ }^{12}$ MDB-Myasishchev Design Bureau, Zhukovsky-5, Moscow Region, Russia \\ ${ }^{13}$ UPMC Univ. Paris 06, Université Versailles St-Quentin, CNRS/INSU, LATMOS-IPSL, Paris, France \\ * now at: KNMI, De Bilt, The Netherlands
}

Received: 3 December 2010 - Published in Atmos. Chem. Phys. Discuss.: 10 January 2011

Revised: 16 May 2011 - Accepted: 6 June 2011 - Published: 16 June 2011

\begin{abstract}
In situ measurements of ice crystal size distributions in tropical upper troposphere/lower stratosphere (UT/LS) clouds were performed during the SCOUT-AMMA campaign over West Africa in August 2006. The cloud properties were measured with a Forward Scattering Spectrometer Probe (FSSP-100) and a Cloud Imaging Probe (CIP) operated aboard the Russian high altitude research aircraft M-55 Geophysica with the mission base in Ouagadougou, Burkina Faso. A total of 117 ice particle size distributions were obtained from the measurements in the vicinity of Mesoscale Convective Systems (MCS). Two to four modal lognormal size distributions were fitted to the average size distributions for different potential temperature bins. The measurements showed proportionately more large ice particles compared to
\end{abstract}

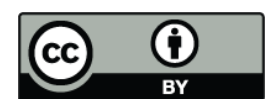

Correspondence to: S. Borrmann (stephan.borrmann@mpic.de) former measurements above maritime regions. With the help of trace gas measurements of $\mathrm{NO}, \mathrm{NO}_{\mathrm{y}}, \mathrm{CO}_{2}, \mathrm{CO}$, and $\mathrm{O}_{3}$ and satellite images, clouds in young and aged MCS outflow were identified. These events were observed at altitudes of $11.0 \mathrm{~km}$ to $14.2 \mathrm{~km}$ corresponding to potential temperature levels of $346 \mathrm{~K}$ to $356 \mathrm{~K}$. In a young outflow from a developing MCS ice crystal number concentrations of up to $(8.3 \pm 1.6) \mathrm{cm}^{-3}$ and rimed ice particles with maximum dimensions exceeding $1.5 \mathrm{~mm}$ were found. A maximum ice water content of $0.05 \mathrm{~g} \mathrm{~m}^{-3}$ was observed and an effective radius of about $90 \mu \mathrm{m}$. In contrast the aged outflow events were more diluted and showed a maximum number concentration of $0.03 \mathrm{~cm}^{-3}$, an ice water content of $2.3 \times 10^{-4} \mathrm{~g} \mathrm{~m}^{-3}$, an effective radius of about $18 \mu \mathrm{m}$, while the largest particles had a maximum dimension of $61 \mu \mathrm{m}$.

Close to the tropopause subvisual cirrus were encountered four times at altitudes of $15 \mathrm{~km}$ to $16.4 \mathrm{~km}$. The mean ice particle number concentration of these encounters was

Published by Copernicus Publications on behalf of the European Geosciences Union. 
$0.01 \mathrm{~cm}^{-3}$ with maximum particle sizes of $130 \mu \mathrm{m}$, and the mean ice water content was about $1.4 \times 10^{-4} \mathrm{~g} \mathrm{~m}^{-3}$. All known in situ measurements of subvisual tropopause cirrus are compared and an exponential fit on the size distributions is established for modelling purposes.

A comparison of aerosol to ice crystal number concentrations, in order to obtain an estimate on how many ice particles may result from activation of the present aerosol, yielded low ratios for the subvisual cirrus cases of roughly one cloud particle per 30000 aerosol particles, while for the MCS outflow cases this resulted in a high ratio of one cloud particle per 300 aerosol particles.

\section{Introduction}

Tropical convective clouds and Mesoscale Convective Systems (MCS) are key elements of the hydrological cycle, the exchange of air masses between troposphere and stratosphere (Pommereau, 2010), the global circulation (Houze, 2004; Schumacher et al., 2004), and with this, key elements of the global climate. The uppermost parts of MCSs consist of large anvils and surrounding cold cloud shields as cirrus decks which can produce detached fields of upper tropospheric cirrus and subvisual cirrus (Houze, 2004; Thomas et al., 2002). Both kinds of ice clouds influence the Earth's radiative budget (Ackerman et al., 1988; Davis et al., 2010, and references therein). Furthermore, MCSs vertically redistribute latent heat and provide fast pathways for upward transport of air from the boundary layer to the upper troposphere/lower stratosphere (UT/LS). Of particular interest in this context are the West African MCSs which occur during the monsoon wet season in the months of July and August with an average frequency near 86 per season (Barnes, 2001; Protat et al., 2010).

Based on observations in 1986 and 1987 West African MCSs are found to have an average lifetime of $11.5 \mathrm{~h}$, form in the evening near 21:00 local time (LT), reach their maximum extent around 02:00 LT, and dissipate in the mornings near 08:30 LT (Barnes, 2001). Between pressure altitude levels from $700 \mathrm{hPa}$ to $100 \mathrm{hPa}$ West African MCSs have significantly higher buoyancy than those over the Maritime Continent (i.e. Southeast Asia) or the Bay of Bengal. As a consequence convection might be deeper over West Africa and the resulting strong updraughts produce stronger precipitation events with larger hydrometeors (Cetrone and Houze, 2009), as suggested by analysis of radar data from the Tropical Rainfall Measuring Mission (TRMM) satellite. Another consequence is that MCSs frequently extend to altitudes above $\approx 14 \mathrm{~km}$ and penetrate the bottom layer of the Tropical Transition Layer (TTL; as defined by Park et al., 2007). The MCS outflows typically occur at altitudes between $12 \mathrm{~km}$ and $16 \mathrm{~km}$ and detrain trace gases and aerosols or ozone precursor gases (Homan et al., 2010; Fierli et al., 2011) into the
TTL. Such processes significantly influence the aerosol and water content of the TTL (Fueglistaler et al., 2009), as well as the chemical composition of the air within the UT/LS (Huntrieser et al., 2009; Barret et al., 2010). Mesoscale model simulations together with in situ observations of various trace gases lead to the conclusion that detrainment residues from deep convection of MCS can be found at altitudes as high as $17 \mathrm{~km}$ (Fierli et al., 2011). Within the TTL air masses carried aloft from the boundary layer by local deep convection encounters air transported into the region from long distances. Domain filling trajectory analyses of air mass origins for the West African TTL of August 2006 indicate that roughly $39 \%$ of the air masses below $370 \mathrm{~K}$ were influenced by lower tropospheric air from Asia, India, and oceanic regions (Law et al., 2010). In the lower TTL here, Law et al. (2010) estimated that about $50 \%$ of the air masses also were affected by local convection. For the 2006 West African monsoon wet season in situ $\mathrm{CO}_{2}$ measurements showed that convective outflow imported boundary layer air into the TTL between $350 \mathrm{~K}$ and $370 \mathrm{~K}$ potential temperature levels (Homan et al., 2010) while simultaneous presence of more aged air was demonstrated by means of ozone data. Lightning produces $\mathrm{NO}_{\mathrm{x}}$ and thus, enhanced levels of $\mathrm{NO}$ and $\mathrm{NO}_{\mathrm{y}}$ (Schumann and Huntrieser, 2007; Huntrieser et al., 2009) can be detected inside the MCS outflows. Similarly, trace gases like $\mathrm{CO}$ and $\mathrm{CO}_{2}$ from biomass burning and boundary layer air can be used to identify outflows. Such outflows may consist of cloudy air, where the particles have not completely evaporated yet, or of cloud free air carrying the trace gas signatures. However, not all anvil clouds are necessarily part of an outflow. For example, cloud particles may sediment out of the outflow air stream, extending the anvil downwards. Or pileus clouds may form directly above the anvil (Garrett et al., 2006). Thus, clouds may be present just above or below the outflow without belonging to the direct convective outflow and identification is only possible by the detection of specific trace gases. Occasionally, a fraction of the $\mathrm{SO}_{2}$ entering a $\mathrm{Cb}$ from the boundary layer also reaches the outflow region (Barth et al., 2007, 2001). The high radiation levels lead to enhanced $\mathrm{OH}$ radical production and fast oxidation of the $\mathrm{SO}_{2}$ to $\mathrm{H}_{2} \mathrm{SO}_{4}$ which can trigger new particle formation events inside outflow air (Weigel et al., 2011) and even inside clouds (Lee et al., 2004). Thus, the Cb outflows constitute a source for ultrafine particles and it has been speculated that this affects the chemical particle composition in the lower TTL (Borrmann et al., 2010; Weigel et al., 2011). Therefore, besides ground based, remote sensing, and satellite data, in situ measurements within MCS outflows and the involved MCS cloud parts are important for the characterisation of the TTL air. The same is true for the tropical cirrus. This is of relevance since parts of the TTL air ultimately are lifted into the stratosphere and globally distributed.

Subvisual cirrus (SVC) clouds within the TTL have been frequently detected by satellite platforms (e.g., Winker and Trepte, 1998; Wang et al., 1996; Sassen et al., 2009) and 
occasionally probed by in situ measurements (e.g., McFarquhar et al., 2000; Thomas et al., 2002; Lawson et al., 2008; Davis et al., 2010; Froyd et al., 2010). Although optically thin these clouds are believed to influence the radiative transfer because of their large horizontal extent (McFarquhar et al., 2000; Davis et al., 2010). Furthermore, they play a major role in the context of freeze-drying air ascending in the tropics towards the stratosphere (Jensen et al., 1996, 2001; Luo et al., 2003a; Peter et al., 2003).

The exact mechanisms leading to nucleation and cloud formation in the TTL still are unknown (Froyd et al., 2009, 2010). A stabilisation mechanism for the maintenance of SVC consisting of small particles $(<20 \mu \mathrm{m})$ at the tropical tropopause over long times and large horizontal areas has been suggested by Luo et al. (2003b) based on in situ measurements (Thomas et al., 2002) over the Seychelles in 1999. Their model calculations showed that such a scenario yields a consistent picture in terms of the small particle sizes and number densities observed there, if the vertical wind speeds are in the range of a few $\mathrm{mm} \mathrm{s}^{-1}$. This model, however, fails for the large SVC particles observed by Lawson et al. (2008) and Davis et al. (2010), and the data presented in this paper from West Africa. Jensen et al. (2008) performed different model simulations on the question how ice crystals as large as $100 \mu \mathrm{m}$ can form at the tropopause. Based on these simulations water vapour mixing ratios of at least $2 \mu \mathrm{mol} \mathrm{mol}^{-1}$ and steady vertical speeds of $2 \mathrm{~cm} \mathrm{~s}^{-1}$ are needed to levitate such particles in the TTL. The importance of fluctuations in temperature and vertical wind velocities for the formation and maintenance of subvisual or opaque cirrus has been pointed out by Jensen et al. $(2001,2010)$ and for mid latitude cirrus by Haag and Kärcher (2004). Furthermore, there is a possibility of gravity wave induced shear off of thin cirrus sheets from large $\mathrm{Cb}$ anvils (Wang, 2003).

Here, we present in situ measurements of the tropical UT/LS from the SCOUT-AMMA campaign (Cairo et al., 2010) in Burkina Faso during August 2006:

- observations for MCS anvil ice particle size distributions as function of potential temperature and comparisons with data from the Central Pacific and tropical Australia,

- case studies of the microphysical properties in young and aged West African MCS outflows at the bottom of the TTL,

- evidence for homogeneous new particle formation inside the anvil outflows,

- new data for upper tropospheric West African SVC cloud particle size distributions and a fit function,

- measurements of the fraction of ice cloud particle concentrations to interstitial aerosol particle number densities inside SVC, MCS anvils, and outflows.
With this we provide direct investigations on microphysical properties of the MCS upper cloud parts and their surroundings from an area where data are rare and which is difficult to probe.

\section{Atmospheric context of the SCOUT-AMMA field campaign}

The SCOUT-AMMA field campaign was based in Ouagadougou, Burkina Faso (at $12.2^{\circ} \mathrm{N}, 1.50^{\circ} \mathrm{W}$ ), and took place from 31 July until 16 August 2006, at the beginning of a westerly Quasi-Biennial Oscillation (QBO) phase and within the West African monsoon wet season (Cairo et al., 2010). Here, we briefly describe the atmospheric situation from a trace gas measurement perspective. Homan et al. (2010) used $\mathrm{CO}, \mathrm{CO}_{2}$, and other trace substances to show that convection transported air from the boundary layer into the TTL which significantly influenced the trace gas composition of the air between $350 \mathrm{~K}$ and $370 \mathrm{~K}$ potential temperature, i.e. the outflow region. Based on domain filling trajectory ensembles from West Africa Law et al. (2010) showed that most air masses were already residing in the TTL during the 10 days prior to the measurements. Up to $39 \%$ of the air masses in the mid-TTL below $370 \mathrm{~K}$ were influenced by lower tropospheric air originating from Asia and India. Fierli et al. (2011) demonstrated for the 2006 monsoon season that detrainment effects from deep convection of MCSs are seen at $17 \mathrm{~km}$ altitude and possibly higher. Residues from biomass burning were detected on the M-55 Geophysica flight from 13 August 2006 in the TTL. These were traced back to biomass burning events in central Africa (Real et al., 2010). Khaykin et al. (2009) provide evidence for overshooting convection over West Africa and for hydration within the TTL and lower tropical stratosphere due to evaporation of ice crystals. Finally, isentropic mixing of extratropical stratospheric air and transport across the subtropical tropopause can play a role for the composition of the air in the upper troposphere and TTL (Homan et al., 2010).

\section{Instrumentation for cloud particle, submicron aerosol particle and trace gas measurements}

\subsection{Cloud particle size distributions and ice water content}

A combination of measurements by a modified Particle Measuring Systems (PMS) Forward Scattering Spectrometer Probe (FSSP-100) with Droplet Measurement Technologies (DMT) high speed electronics (SPP-100) and a DMT Cloud Imaging Probe (CIP) was used to derive cloud particle size distributions. These probes cover a size range of $2.7 \mu \mathrm{m}<$ $D_{p}<29.2 \mu \mathrm{m}$ (FSSP-100) and $25 \mu \mathrm{m}<D_{p}<1600 \mu \mathrm{m}$ with a $25 \mu \mathrm{m}$ resolution (CIP). The particles detected by the FSSP100 may not necessarily be cloud ice particles but could also 
Table 1. Applied correction mechanisms for the CIP particle image analysis with the respective references.

\begin{tabular}{|c|c|c|}
\hline $\begin{array}{l}\text { reason for correc- } \\
\text { tion }\end{array}$ & description of solution & reference \\
\hline first slice & reconstruction of lost first slice due to acquisition start-up time & de Reus et al. (2009) \\
\hline area ratio & $\begin{array}{l}\text { rejection of streakers and multiple particles in one image frame due to } \\
\text { an area ratio below } 0.1\end{array}$ & de Reus et al. (2009) \\
\hline out of focus & $\begin{array}{l}\text { size and sample volume correction for out of focus particles that show } \\
\text { a Poisson spot }\end{array}$ & Korolev (2007) \\
\hline empty images & reconstruction as one pixel image & de Reus et al. (2009) \\
\hline shattering & $\begin{array}{l}\text { rejection of particles with interarrival time below a specific threshold } \\
\text { which is chosen for each flight individually }\end{array}$ & Field et al. (2006) \\
\hline partial images & $\begin{array}{l}\text { reconstruction of images that touch an end diode (especially young out- } \\
\text { flow clouds contain large particles), reconstructed particles that exceed } \\
\text { a size of } 3000 \mu \mathrm{m}(\approx \text { twice the array width) are rejected (no complete } \\
\text { rejection as in de Reus et al., } 2009)\end{array}$ & $\begin{array}{l}\text { Heymsfield and Parrish } \\
\text { (1978) }\end{array}$ \\
\hline
\end{tabular}

be supercooled droplets. Furthermore, particles detected in the lowest FSSP-100 size bins may be large aerosols. The characteristics of the instruments are described in detail in de Reus et al. (2009, and references therein). While the time resolution of FSSP-100 measurements was set to $2 \mathrm{~s}$, the CIP detects single cloud particles with a maximum sample rate of $8 \mathrm{MHz}$. Nevertheless, in order to combine with the FSSP100 data also two second averages have been calculated for the CIP data. (For calculation of size distributions longer averaging periods were necessary.) The uncertainties of the number concentration measurements are mainly determined by the uncertainties in the sample volumes, which were estimated to be $20 \%$ (Baumgardner et al., 1992; de Reus et al., 2009) for both probes. Additional uncertainty due to counting statistics has to be taken into account especially in conditions with low particle number concentrations.

In order to derive particle sizes from the CIP images a set of corrections needs to be applied. The underlying types of corrections are summarised in Table 1 (as in de Reus et al., 2009 , if not specified otherwise) together with a short description and the corresponding references. The particle diameters derived from CIP measurements are specified in this paper by using the maximum dimension (Heymsfield et al., 2002). The Ice Water Content (IWC) was calculated using the scheme of Baker and Lawson (2006) in order to take into account the shape of the ice particles. The effective radius $\left(r_{\text {eff }}\right)$, as a measure for the cloud radiative properties, is defined here as the ratio of the third to the second moment of a size distribution, in terms of spheres of equivalent crosssection area (McFarquhar and Heymsfield, 1998).

\subsubsection{Shattering of ice particles on the cloud particle probes}

A widely discussed problem for in situ ice particle measurements is the shattering of ice crystals on the probe's arm tips and shrouds or inlets (e.g. Field et al., 2006; Lawson et al., 2008; Jensen et al., 2009; Korolev et al., 2011; Lawson, 2011). Since clouds in MCS outflows are likely to contain large particles and possibly high number concentrations, artefacts introduced by shattering have to be considered. In contrast, the subvisual tropopause cirrus do not contain large particles (i.e. most particles are smaller than $\approx 100 \mu \mathrm{m}$ ) such that shattering can be assumed to be of minor or negligible impact (Lawson et al., 2008; Jensen et al., 2009). Furthermore, these clouds only have low number concentrations of particles. Also measurements in young contrails have been found to not be affected by shattering (Voigt et al., 2010).

For the cirrus clouds encountered by the M-55 Geophysica during the tropical campaigns TROCCINOX (Brazil, 2005; Huntrieser et al., 2007), SCOUT-O3 (Australia, 2005; Brunner et al., 2009; Vaughan et al., 2008), and SCOUT-AMMA intercomparisons were performed between the directly measured volume backscatter ratio (from the MAS instrument, see Sect. below) and the corresponding values calculated from the FSSP-100 size distributions by Cairo et al. (2011). According to their study the fraction of the size distribution detected by the FSSP-100 (i.e., $2.7 \mu \mathrm{m}$ to $29.2 \mu \mathrm{m}$ ) well reproduces the cirrus optical properties in the visible part of the spectrum extending over backscattering cross sections of five orders of magnitude. If the FSSP-100 measurements had suffered from significant artificial enhancements by shattered ice particle fragments, the backscatter cross sections derived from FSSP-100 size distributions would differ from the MAS results because in this size range the backscatter ratio sensitively depends on the size distribution. For this reason we believe that shattering does not play a major role under the circumstances encountered in the cirrus clouds analysed by Cairo et al. (2011).

However, to further cope with shattering artefacts the interarrival time technique, as proposed by Field et al. 
(2006), has been applied to the CIP data set. Therefore, the interarrival time threshold, below which particles are rejected, has been chosen individually for each flight according to the measurement characteristics and ranged between $2.6 \times 10^{-6} \mathrm{~s}$ and $5 \times 10^{-6} \mathrm{~s}$. Unfortunately, the interarrival time method is not applicable for FSSP-100 measurements. However, with this technique time periods can be identified from the CIP data where measurements are affected by shattering. In case that there is very little or no shattering obvious in the CIP data, shattering is assumed to be within the instrument uncertainty for FSSP-100 data. In these cases the size distributions of both instruments show a good agreement for the size range ( $25 \mu \mathrm{m}$ to $29.2 \mu \mathrm{m})$ where both instruments overlap. When looking at the frequency of occurrence of shattering, in $41 \%$ of the two second measurement time steps (i.e. data points) where clouds occurred no shattering has been measured by the CIP. For $85 \%$ of the data points with cloud occurrence the fraction of shattered particles is less than $20 \%$ of the total number of observed particles. This lies within the instrumental uncertainty of the CIP. In the figures below the FSSP-100 size range of particular size distributions is highlighted with a shading in case that the CIP reports a fraction of shattered particles $\geq 10 \%$. It has to be noted that the highest contribution to shattering was measured on the flight of 16 August, 2006, where only $8 \%$ of the cloud data were not affected by shattering. Data are eliminated from further analyses in case that there is a high fraction of shattering in the CIP measurements. Size distributions also are excluded from further analyses in cases where the CIP and FSSP-100 size distributions do not make up a good match in the overlapping size range. This is so far the best possible approach until studies become available which quantify the shattering of the FSSP-100 as function of cloud particle size and number densities in cirrus clouds, as well as aircraft speed and ambient pressure. For this reason the results from the FSSP-100 measurements presented here constitute an upper limit estimate on the size distributions while the CIP data are fully corrected for shattering effects according to the current status of technology. A detailed discussion about shattering and cloud particle probe performance is provided in the Supplement.

\subsection{Submicron aerosol particle number densities, and optical properties}

Ambient aerosol number concentrations were measured for particles with size diameters between lower detection limits (in terms of $50 \%$ "cut off") of $6 \mathrm{~nm}\left(N_{6}\right), 10 \mathrm{~nm}\left(N_{10}\right)$, $15 \mathrm{~nm}\left(N_{15}\right)$ and roughly $1 \mu \mathrm{m}$ as upper limit by three channels of the COndensation PArticle counting System (COPAS; Curtius et al., 2005; Weigel et al., 2009; Borrmann et al., 2010). In a fourth channel the sampled aerosol was heated to $250^{\circ} \mathrm{C}$ such that only particles containing non-volatile residues (with sizes above $10 \mathrm{~nm}$ ) were detected and counted. The total accuracy is $\pm 10 \%$ and COPAS samples with a frequency of $1 \mathrm{~Hz}$. New particle formation (NPF) or nucleation events were encountered during some of the flights. These are associated with particle number densities $N_{6}$ being much larger than $N_{15}$ or $N_{10}$ as well (see Weigel et al., 2011, for detailed description). Part of the M-55 Geophysica instrumentation was a Multiwavelength Aerosol Scatterometer (MAS; for details see Cairo et al., 2004; Buontempo et al., 2006; Cairo et al., 2010), which is a backscatter sonde for in situ measurements of optical air, aerosol, and cloud parameters like volume backscatter ratio and depolarisation ratio (at $532 \mathrm{~nm}$ and $1064 \mathrm{~nm}$ ). MAS samples with a time resolution of $5 \mathrm{~s}$ and has a precision of $10 \%$.

\subsection{Gas-phase species: $\mathrm{NO}_{\mathrm{y}}, \mathrm{NO}, \mathrm{CO}, \mathrm{CO}_{2}, \mathrm{O}_{3}$, and $\mathrm{H}_{2} \mathrm{O}$}

Air originating from the cloud interior can be identified within MCS outflows by using trace gas data of $\mathrm{CO}, \mathrm{CO}_{2}$, $\mathrm{NO}_{\mathrm{y}}$, and NO.

Nitrogen oxide, $\mathrm{NO}$, and reactive nitrogen species, $\mathrm{NO}_{\mathrm{y}}$ were measured aboard the M-55 Geophysica with the StratospherIc Observation Unit for nitrogen oXides (SIOUX) two channel $\mathrm{NO}_{\mathrm{y}}$ instrument (Voigt et al., 2005, 2007, 2008). During SCOUT-AMMA on most flights NO and gas phase $\mathrm{NO}_{\mathrm{y}}$ were measured with two backward facing inlets of the SIOUX instrument using the chemiluminescence technique. In the $\mathrm{NO}_{\mathrm{y}}$ channel gas phase $\mathrm{NO}_{\mathrm{y}}$ is catalytically reduced to $\mathrm{NO}$ with $\mathrm{CO}$ in a gold converter heated to $300^{\circ} \mathrm{C}$. Thereafter the chemiluminescence reaction of $\mathrm{NO}$ with $\mathrm{O}_{3}$ in the infrared is detected with two photomultipliers. The instrumental error is $10 \%$, and the detection limit for $\mathrm{NO}$ and $\mathrm{NO}_{\mathrm{y}}$ is better than $1 \mathrm{pmol} \mathrm{mol}^{-1}$ and $5 \mathrm{pmol} \mathrm{mol}^{-1}$ for a sampling frequency of $1 \mathrm{~Hz}$.

$\mathrm{CO}_{2}$ mixing ratios were measured in situ on the M-55 Geophysica by a non-dispersive infrared absorption sensor (LI-COR 6251) that is part of the High Altitude Gas Analyzer (HAGAR), which also comprises a 2-channel gas chromatograph (Volk et al., 2000; Homan et al., 2010). For the $\mathrm{CO}_{2}$ measurements during SCOUT-AMMA the time resolution was $5 \mathrm{~s}$ and the flight-to-flight precision about $0.3 \mu \mathrm{mol} \mathrm{mol}{ }^{-1}$.

Mainly for the identification of biomass burning events in situ carbon monoxide measurements were performed by the Cryogenically Operated Laser Diode (COLD; Viciani et al., 2008 ) instrument, which has at a lower detection limit of a few $\mathrm{nmol} \mathrm{mol}^{-1}$, an accuracy of $6-9 \%$ and a precision of $1 \%$.

Ozone mixing ratios were obtained at $1 \mathrm{~Hz}$ sampling rate from the Fast OZone ANalyzer (FOZAN; Yushkov et al., 1999; Ulanovsky et al., 2001) with an accuracy of $10 \%$.

Total water was measured as sum of water condensed in ice particles and gas phase water with a forward facing inlet by means of a Fast In situ Stratospheric Hygrometer (FISH). Its Lyman- $\alpha$ photofragment fluorescence technique is described in Zöger et al. (1999). Due to the inlet 
geometry the ice particles are sampled with an enhancement, thus, the contribution of ice to the total water has to be corrected afterwards. The methods underlying the ice particle detection are described in Schiller et al. (2008). The rearward/downward facing FLuorescent Airborne Stratospheric Hygrometer (FLASH) (Khaykin et al., 2009; Sitnikov et al., 2007) was used to measure only the gas phase water such that the ice water content could be determined in conjunction with the FISH total water. In combination with concurrent temperature measurements also the saturation with respect to ice could be calculated. The uncertainties of the FISH data are $6 \%$ or $0.2 \mu \mathrm{mol} \mathrm{mol}^{-1}$ and the corresponding values for FLASH are $8 \%$ and $0.3 \mu \mathrm{mol} \mathrm{mol}^{-1}$ (Krämer et al., 2009).

The ambient temperature was measured using a Thermo Dynamic Complex (TDC) with an accuracy of $0.5 \mathrm{~K}$ (Shur et al., 2007) which leads to a measurements uncertainty for the relative humidity with respect to ice $(\mathrm{RH} i)$ of $12-17 \%$ (Krämer et al., 2009). Other relevant parameters as position and true air speed have been adopted from the aboard navigational system UCSE (Unit for Connection with the Scientific Equipment; Sokolov and Lepuchov, 1998).

In West Africa the ambient and operational conditions on the ground and during the flights were extremely challenging for all instruments. For this reason the measured parameters are not always available for each flight or the entire flight.

\section{Results and analyses}

The data base from the SCOUT-AMMA campaign includes data of a total of nine flights. The FSSP-100 and CIP were operated simultaneously during five flights: $7,8,11,13$, and 16 August 2006 (transfer flight). During one flight (13 August 2006) only low level clouds have been probed.

\subsection{Overview of the MCS anvil measurements}

During the SCOUT-AMMA flights of the M-55 Geophysica anvils of MCS were penetrated at altitudes between $345 \mathrm{~K}$ and $365 \mathrm{~K}$ of potential temperature altitude. The ice particle size distributions from these encounters are shown in Fig. 1 including some distributions from SVC in the fourth and fifth panels from below. The measurements were performed with averaging times of 10-20 s resulting in good counting statistics for the majority of the cases. In the other cases, as for example encounters of SVC (see Sect. 4.5) with low number concentrations the averaging time needed to be individually adapted and ranges up to $200 \mathrm{~s}$. All size distributions are classified in $5-10 \mathrm{~K}$ bins of potential temperature $\left(T_{\text {potential }}\right)$ and are normalised to a total $d N / d \log D_{p}$ value of 1 (similar as in de Reus et al., 2009). The thin black lines represent the individual measurements while the red lines denote the median size distribution of each potential temperature bin. It can be seen that the maximum particle sizes are decreasing when ascending into the tropopause region

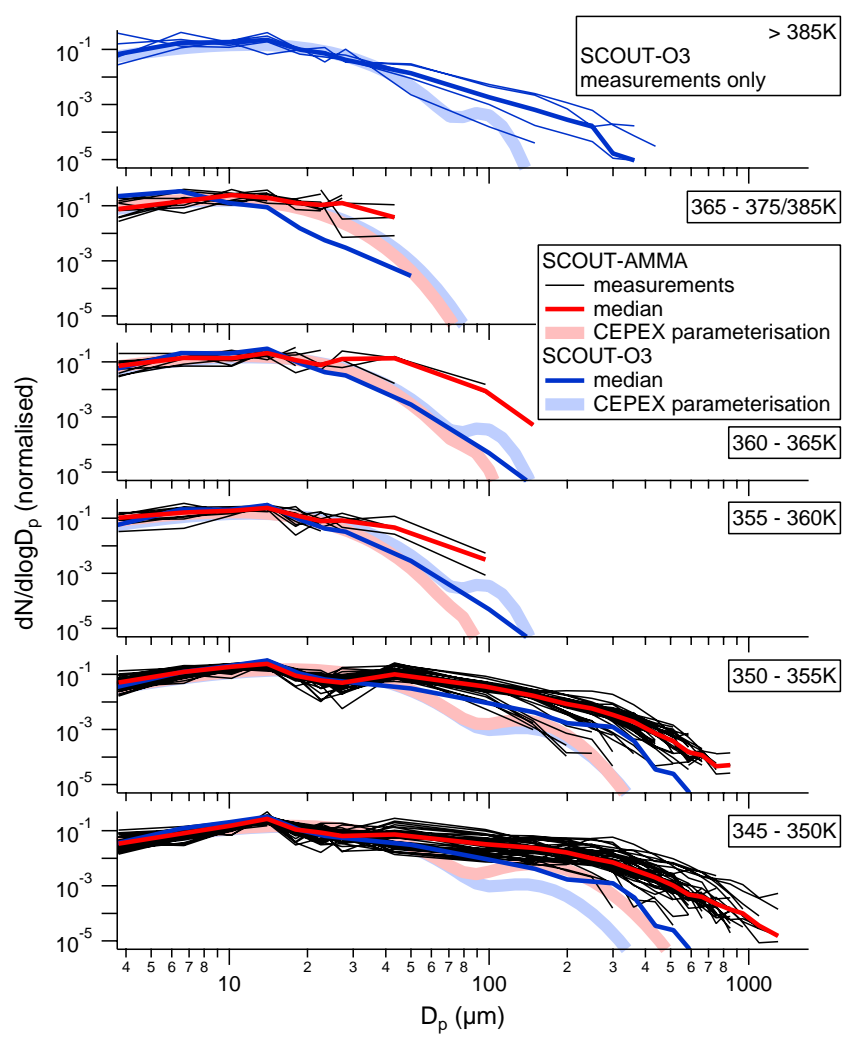

Fig. 1. Normalised ice particle size distributions of the cloud encounters during SCOUT-AMMA (black lines) in West Africa (2006): medians of the in situ measurements are displayed in bright red. The shaded pale red curves result from the CEPEX parameterisation after McFarquhar and Heymsfield (1997). For comparison M-55 Geophysica data from the Hector MCS in Northern Australia (during the 2005 SCOUT-O3 campaign) are shown with medians in bright blue and a corresponding CEPEX parameterisation in shaded pale blue (from de Reus et al., 2009).

$\left(365 \mathrm{~K}<T_{\text {potential }}<385 \mathrm{~K}\right)$. This agrees with the measurements obtained during the SCOUT-O3 campaign in Northern Australia (de Reus et al., 2009), of which the medians are shown in blue. (Note: de Reus et al. (2009) used 10-20 K bins, i.e. $345-355 \mathrm{~K}, 355-365 \mathrm{~K}$, and $365-385 \mathrm{~K}$.) In that study also stratospheric clouds, originating from $\mathrm{Cb}$ overshoots, had been probed and are displayed here as thin blue lines in the uppermost panel $\left(T_{\text {potential }}>385 \mathrm{~K}\right)$ for comparison. A parameterisation for tropical cirrus had been derived from ice crystal size distribution measurements during the Central Equatorial Pacific Experiment (CEPEX) by McFarquhar and Heymsfield (1997). Tropical anvil cirrus had been probed there with ice water contents ranging from $10^{-4}$ to $1 \mathrm{~g} \mathrm{~m}^{-3}$ and at ambient temperatures between $253 \mathrm{~K}$ and $203 \mathrm{~K}$. Adopting the CEPEX parameterisation, curves of the normalised particle size distributions were calculated for the West African and Australian measurements. For this the average IWCs and ambient temperatures as observed are 
taken as input for the calculations. We have to note that the temperatures observed during the SCOUT-AMMA campaign were lower (i.e., ranging between $195 \mathrm{~K}$ and $210 \mathrm{~K}$ ) than during CEPEX. The results of the calculations are shown in the broad pale red lines for SCOUT-AMMA and in the broad pale blue lines for SCOUT-O3. The size distributions resulting from the parameterisations have a similar decrease in maximum particle size with increasing potential temperature in the troposphere. However, they show a more pronounced mode at diameters of 100-200 $\mu \mathrm{m}$, which is not present in our observations. Furthermore, the comparison shows clearly that less large particles have been observed during CEPEX in the two lowest potential temperature bins. In the $355-365 \mathrm{~K}$ bins measurements are fewer but still particle sizes are larger than those calculated from the parameterisation. Particularly in the CIP size range, the shape of the size distributions indicates a higher fraction of large particles than observed during CEPEX. Since the CEPEX parameterisation is a result of measurements from the Maritime Continent while SCOUTAMMA took place over West Africa, the discrepancy may be indicative of a conclusion by Cetrone and Houze (2009). According to them the convection over West Africa might be deeper and produces stronger precipitation with larger hydrometeors, due to the dry adiabatic temperature profiles there, than compared to the Maritime Continent. Also Hall and Peyrille (2006) point out that due to the capping Saharan Air Layer (SAL) it is more usual that deep convection occurs in large scale energetic systems in West Africa. However, such interpretations need to be viewed with caution because of the small data base and of the large intrinsic variability in clouds.

In order to describe the ice particle size distributions from SCOUT-AMMA for each potential temperature bin (as in Fig. 1) two, three, or in one case four modal lognormal distributions are fitted to the now not normalised median size distribution $n_{*}\left(D_{p}\right)$, following

$$
\begin{aligned}
n_{*}\left(D_{p}\right) & =\frac{d N}{d \log D_{p}} \\
& =\sum_{i}\left(\frac{N_{i}}{\sqrt{2 \pi} \log \sigma_{i}} \exp \left[-\frac{\left(\log D_{p}-\log \overline{D_{p i}}\right)^{2}}{2\left(\log \sigma_{i}\right)^{2}}\right]\right) .
\end{aligned}
$$

Here, $D_{p}$ is the particle diameter in $\mu \mathrm{m}, i$ the number of modes (two to four), $N$ the number concentration $\left(\mathrm{cm}^{-3}\right)$, $\overline{D_{p}}$ the mean mode diameter $(\mu \mathrm{m})$, and $\sigma$ the standard deviation. The $n_{*}\left(D_{p}\right)=d N / d \log D_{p}$ values result in $\mathrm{cm}^{-3}$. The parameters of the fitted functions are listed in Table 2, similar to Table 1 in de Reus et al. (2009) for the SCOUT-O3 measurements in Northern Australia.
Table 2. Parameters as defined in Eq. (2) for the two to four modal lognormal size distributions fitted to the median size distribution for each temperature bin as shown in Fig. 1.

\begin{tabular}{clclc}
\hline$T_{\text {potential }}(\mathrm{K})$ & $N\left(\mathrm{~cm}^{-3}\right)$ & $\overline{D_{p}}(\mu \mathrm{m})$ & $\sigma$ & Mode\# \\
\hline $365-375$ & 0.0036 & 6.6 & 1.5 & 1 \\
& 0.0017 & 15.3 & 1.23 & 2 \\
$360-365$ & 0.012 & 9.5 & 1.7 & 1 \\
& 0.0045 & 38 & 1.5 & 2 \\
$355-360$ & 0.021 & 9.5 & 1.7 & 1 \\
& 0.0025 & 40 & 1.4 & 2 \\
$350-355$ & 0.15 & 9.5 & 1.6 & 1 \\
& 0.08 & 49 & 1.55 & 2 \\
$345-350$ & 0.007 & 180 & 1.55 & 3 \\
& 0.13 & 10 & 1.55 & 1 \\
& 0.025 & 40 & 1.55 & 2 \\
& 0.018 & 160 & 1.6 & 3 \\
& 0.00015 & 900 & 1.2 & 4 \\
\hline
\end{tabular}

\subsection{Case study 1: young MCS outflow in the West African upper troposphere}

\subsubsection{Atmospheric context and gas phase species}

During the descent of the flight on 7 August 2006 the M55 Geophysica crossed a layer of air which can be characterised as young or recent outflow from a developing MCS. Trajectory analysis (Fierli et al., 2011) indicate an age of less than three hours, i.e. the time between the measurements and the time when the trajectories intersected with the convective core region in the past. The EUMETSAT/ESA Meteosat Second Generation satellite image of the MCS constellation at the time of the measurements is shown in Fig. 2 together with the M-55 Geophysica flight track, in blue for the concurrent part of the satellite image, in red for the whole flight. In Fig. 3 the vertical profile measurements are displayed for: temperature $(T)$, relative humidity with respect to ice $(\mathrm{RH} i)$, $\mathrm{O}_{3}, \mathrm{NO}, \mathrm{NO}_{\mathrm{y}}$, cloud particle concentrations $\left(N_{\text {cloud }}\right)$, and ice water content (IWC), as well as the $N_{15}$ and ultrafine particle concentrations (denoted as $N_{6-15}=N_{6}-N_{15}$ in the figures). The thermal tropopause was located at $370 \mathrm{~K}$ and well defined. Below $355 \mathrm{~K}$ a layer of air was located which had relative humidities between $60 \%$ and $120 \%$ (occasionally up to $140 \%$ ), and contained an ice cloud with IWCs around $5 \times 10^{-3} \mathrm{~g} \mathrm{~m}^{-3}$ and with ice particle number densities of roughly $5 \mathrm{~cm}^{-3}$. Slightly enhanced $\mathrm{CO}$ mixing ratios have been observed in this cloud band. In the lower part of the cloud (below $350 \mathrm{~K}$ ) elevated $\mathrm{NO}$ and $\mathrm{NO}_{\mathrm{y}}$ mixing ratios were detected, even reaching values above $10 \mathrm{nmol} \mathrm{mol}^{-1}$. These constitute very high values, indicating that the cloud layer is a young outflow from the small $(\approx 60 \mathrm{~km}$ in diameter) deep convective system at the Eastern part of the blue flight track line in Fig. 2, which is a just developing MCS. (Note: the general flow direction as seen from subsequent 


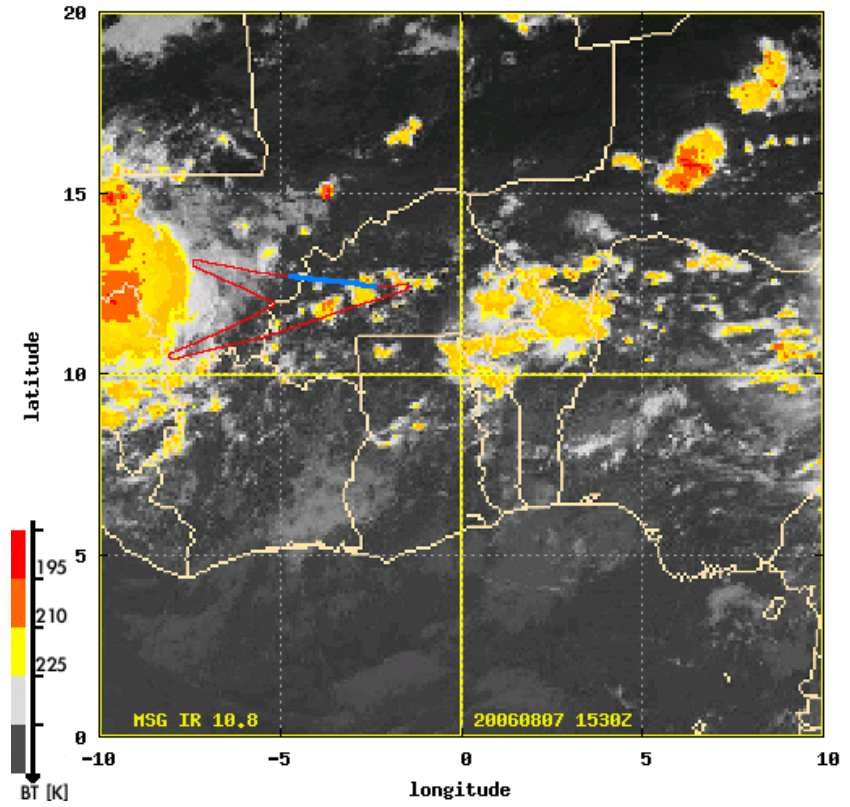

Fig. 2. Meteosat Second Generation (MSG) satellite image of Mesoscale Convective Systems (MCS) on 7 August 2006. The flight track of the M-55 Geophysica is indicated by the red/blue line. The blue part shows the flight segment of the time period for which the satellite image is valid and approximately where the measurements of Fig. 3 were performed.

satellite images and trajectory analyses is from East to West in this location and altitude band.) The presence of slightly elevated cloud particle number densities and IWCs in the fourth panel of Fig. 3 between $365 \mathrm{~K}$ and $370 \mathrm{~K}$ show an SVC which was located $500 \mathrm{~m}$ beneath the tropopause. This cirrus Case SVC2 is further discussed in Sect. 4.5.

\subsubsection{Aerosol and cloud measurements}

A zoom-in on the flight data time series during the cloud layer crossing is shown in Fig. 4 and selected cloud particle size distributions of the time periods which are shaded in blue are compiled in Fig. 5. These are labelled as above-outflow Cases "AOF1" and "AOF2", and outflow Cases "OF1" and "OF2". Obviously, the cloud layer vertically extended from $13.2 \mathrm{~km}$ to $11.0 \mathrm{~km}$ altitude and within this cloud band three sub-layers can be discerned. The uppermost sub-layer (denoted as "Sub-layer 1" in Fig. 4) stretched from $13.2 \mathrm{~km}$ to $12.2 \mathrm{~km}$. It contained lower cloud particle concentrations, compared to the sub-layers below, in coincidence with a strong in-cloud New Particle Formation event (NPF). The details of this NPF are analysed in Weigel et al. (2011) and juxtaposed with other NPFs in the tropical UT/LS from different locations. Based on the ice particle data this cloud segment can be considered as part of the developing MCS anvil but the low values for $\mathrm{NO}$ and $\mathrm{NO}_{\mathrm{y}}$ indicate that this is not an outflow from the MCS. The cloud "Sub-layer 2" (12.1-11.9 km) also was a part of the MCS anvil where the cloud particle number density increased by almost a factor of 10 and where the nucleation event was "quenched". Below "Sub-layer 2", cloud "Sub-layer 3" (Fig. 4) extended between $11.9 \mathrm{~km}$ and $11.0 \mathrm{~km}$ involving high particle number concentrations and very high values for $\mathrm{NO}$ and $\mathrm{NO}_{\mathrm{y}}$. Since soil emissions may contribute up to $1 \mathrm{nmol} \mathrm{mol}^{-1}$ (Stewart et al., 2008), the mixing ratios observed here give a clear indication for production in lightning. Thus, this is the outflow where the detrainment must have occurred very recently, since the elevated NO and $\mathrm{NO}_{\mathrm{y}}$ had not been diluted yet. Also very little of the NO had been oxidised to $\mathrm{NO}_{\mathrm{y}}$ by the time of the measurement. From the enlarged satellite image and the flight track of the aircraft one can estimate that the sampling occurred at a maximum distance of roughly $30 \mathrm{~km}$ from the convective core. The cloud particle size distributions show that the clouds at the highest cloud level in "Sub-layer 1" contained no particles larger than $400 \mu \mathrm{m}$. As the aircraft descended, the concentrations and particle sizes increased to $8 \mathrm{~cm}^{-3}$ and $1.6 \mathrm{~mm}$, respectively. During "AOF2" and in particular during "OF1" it can be assumed that there also were particles with sizes much above the CIP detection limit. Examples of some individual cloud particle shadow cast images obtained from the CIP are shown in Fig. 6. As far as one can tell from visual inspection these mostly seem to be heavily rimed ice particles or rimed aggregates. Ambient temperatures during this cloud crossing were below $-47^{\circ} \mathrm{C}$, thus, the observed cloud particles are ice particles.

\subsection{Case study 2: aged MCS outflow at $14 \mathrm{~km}$ altitude}

\subsubsection{Atmospheric context}

On 11 August 2006 the M-55 Geophysica flew through a region behind a squall line with horizontal extension of approximately $1000 \mathrm{~km}$ (see the cloud band roughly aligned with the $-3^{\circ} \mathrm{W}$ meridian in the satellite image of Fig. 7). The structure of this particular MCS is described in Chong (2010) using data by the MIT Doppler radar. The aircraft crossed the outflow region between $300 \mathrm{~km}$ and $400 \mathrm{~km}$ behind the squall line, which is much further away from the MCS core region than in Case study 1. Although $\mathrm{NO}$ and $\mathrm{NO}_{\mathrm{y}}$ measurements are not available from this flight, it can be assumed that a more aged MCS outflow air mass was probed than on $7 \mathrm{Au}-$ gust 2006. Trajectory analysis indicate an age of these outflow clouds of about $10 \mathrm{~h}$ (Fierli et al., 2011). Here, we use $\mathrm{CO}_{2}$ data to identify outflow regions.

\subsubsection{Overview of vertical profiles}

The vertical profiles of the measured variables are presented in Fig. 8. They include measurements from ascent, descent, and one dive. Thus, spreads in the single parameters might result from the profiling at different locations. The thermal tropopause was located near $16.5 \mathrm{~km}$ (i.e., $375 \mathrm{~K}$ ). 


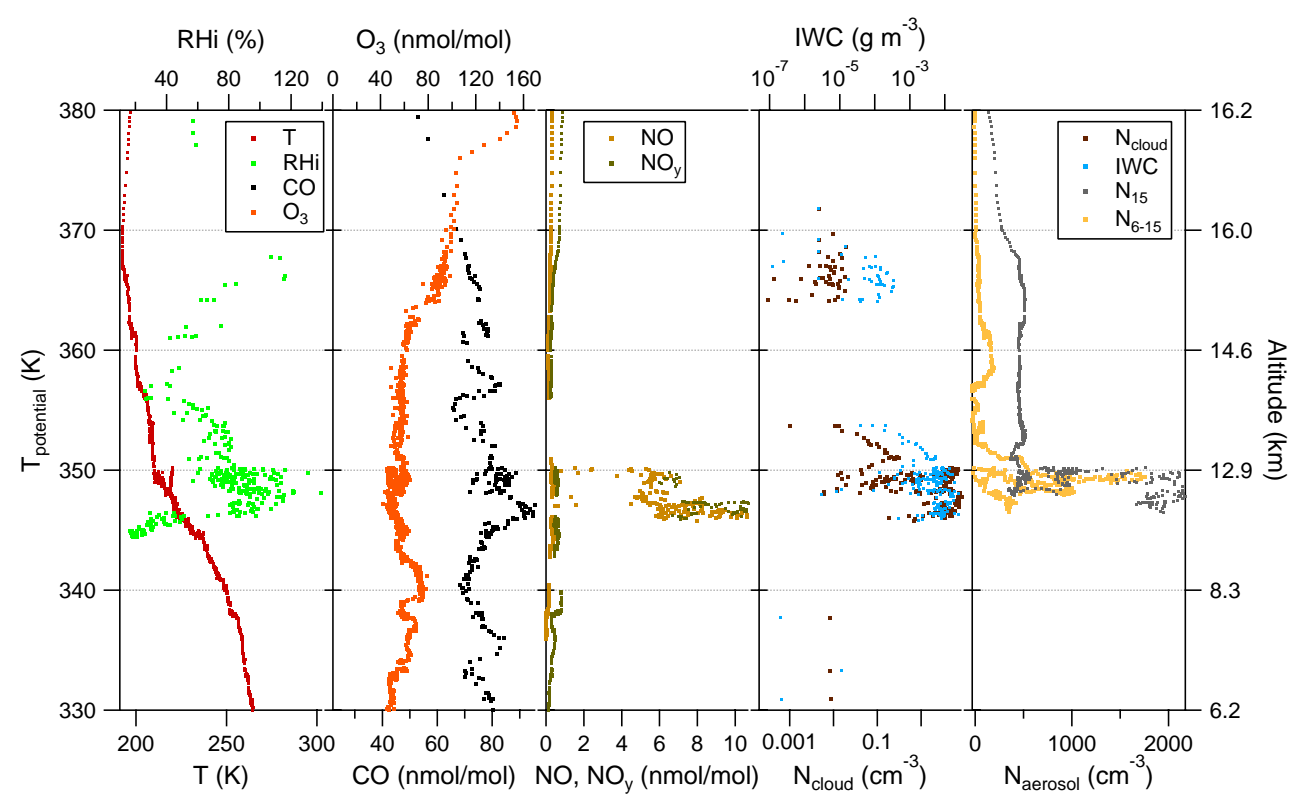

Fig. 3. Vertical profiles recorded by the instruments aboard M-55 Geophysica during its descent into Ouagadougou, Burkina Faso, on 7 August 2006.

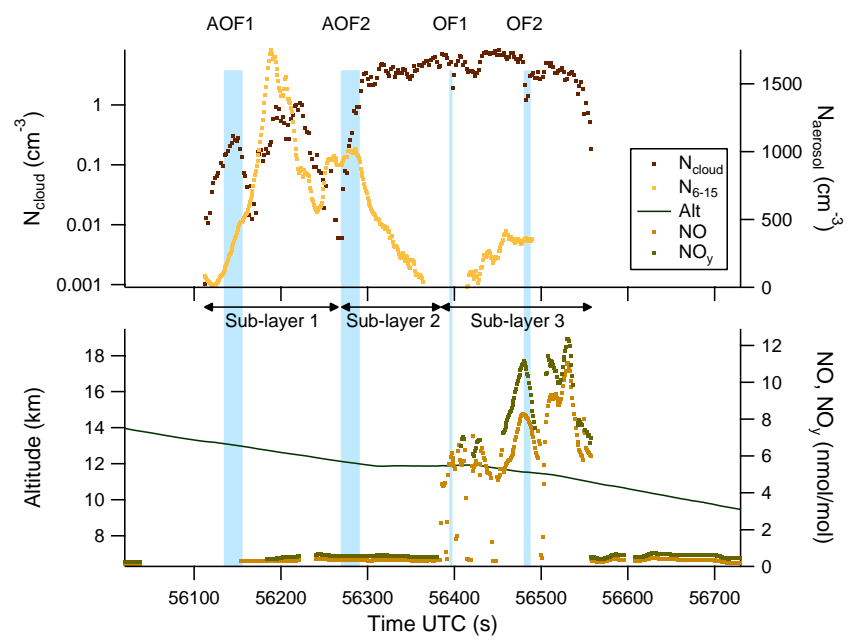

Fig. 4. Time series segment of the MCS anvil and outflow cloud crossing during descent on 7 August 2006. The shadings indicate time periods which were selected for deriving the ice particle size distributions as displayed in Fig. 5. $\left(N_{6-15}\right.$ denotes the concentration difference $N_{6}-N_{15}$.)

The relative humidity is presented as ten second running average due to noise in the FLASH measurements during this flight. Therefore, the relative humidity is displayed additionally as calculated from the FISH total water content $\left(\mathrm{RH} i_{\text {enhanced }}\right.$, not corrected for enhanced ice particle sampling, see Sect. 3.3). The cloudy parts show thus a clear enhancement from the gas phase baseline in the relative hu-

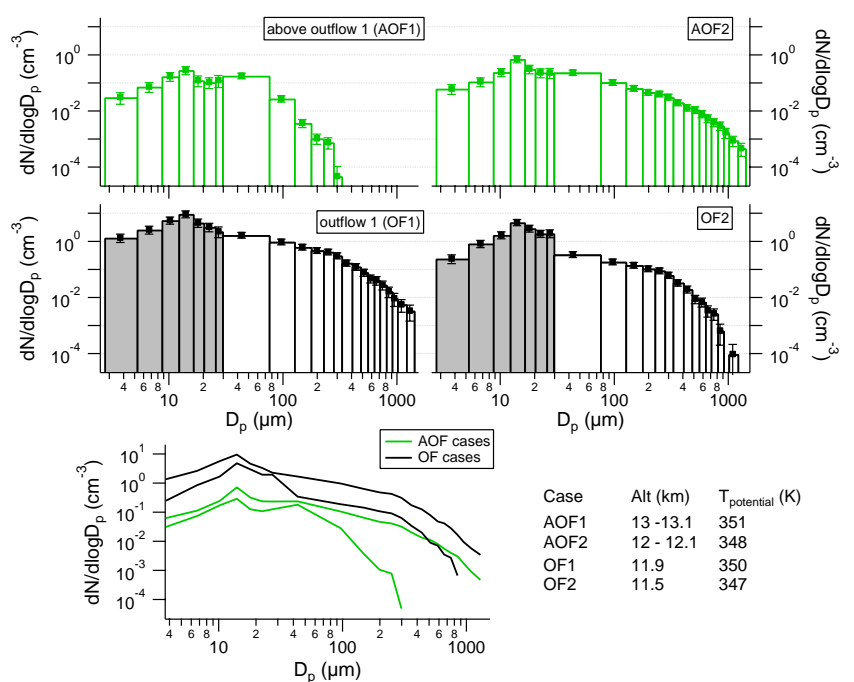

Fig. 5. Cloud particle size distributions measured within the MCS anvil and outflow during descent on 7 August 2006 at the times and for the cases indicated in Fig. 4. The lowest panel summarises the ice particle size distributions of the four upper panels. The shading in the FSSP-100 size range indicates that these measurements are potentially affected by shattering.

midity. The relative humidities from the FLASH and the FISH baselines show good agreement. In the second panel the vertical profile of $\mathrm{CO}_{2}$ exhibits a distinctive minimum between $353 \mathrm{~K}$ and $360 \mathrm{~K}$, which indicates the presence of air from lower altitudes. Most likely this air mass was 


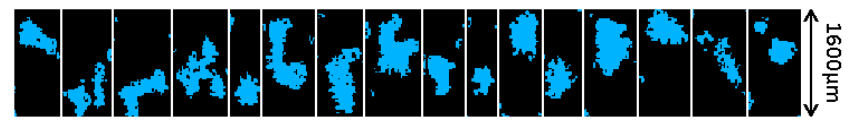

Fig. 6. Examples of cloud particle shadow-cast images collected by the CIP when crossing the MCS anvil and outflow while descending on 7 August 2006.

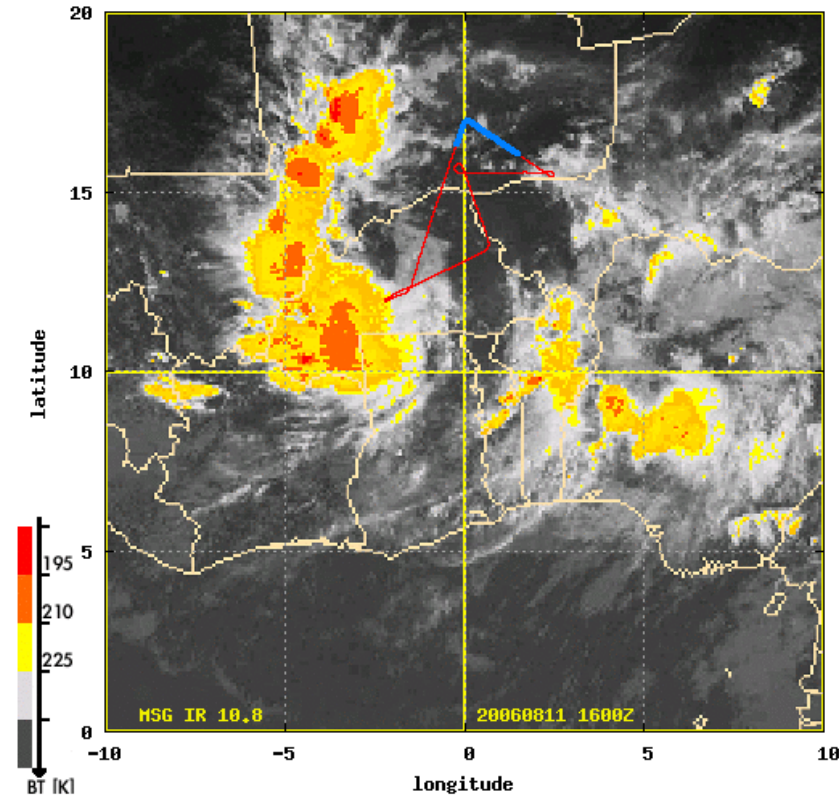

Fig. 7. MSG satellite image of the MCS on 11 August 2006 with the flight track of the M-55 Geophysica as indicated in blue/red.

convectively uplifted from the boundary layer, where the vegetation metabolises $\mathrm{CO}_{2}$. The third panel in Fig. 8 shows that patchy clouds existed at all altitudes above $351 \mathrm{~K}$ up to the tropopause with low ice particle number concentrations $\left(\approx 10^{-2} \mathrm{~cm}^{-3}\right)$. In particular, tenuous clouds were present in the altitude band with the low $\mathrm{CO}_{2}$ mixing ratios. At the same time the remnants of an NPF event are discernible in the fourth panel which partly occurred inside the outflow cloud and partly outside the cloud but still within the outflow (cf. Fig. 9). The ultrafine particle concentrations $\left(N_{6-15}\right)$ attained values as high as $1000 \mathrm{~cm}^{-3}$. Interestingly, the non volatile fraction (see panel 5) of these newly formed aerosol particles is very low $(5 \%)$ inside the outflow while it is much higher $(50 \%-60 \%)$ above. This indicates that the newly formed particles consist mostly of sulfuric acid and water as shown by Weigel et al. (2009) and Curtius et al. (2005).

\subsubsection{New particle formation event}

A closer look on a flight segment from $58200 \mathrm{~s}$ UTC to $58400 \mathrm{~s}$ UTC is presented in Fig. 9. The blue shaded area designates the crossing of a cloud patch as indicated by the
Table 3. Measurement details substantiating the air mass change before and after the NPF peak in Fig. 9 on 11 August 2006.

\begin{tabular}{|c|c|c|}
\hline & $\begin{array}{r}\text { MCS } \\
\text { outflow }\end{array}$ & $\begin{array}{r}\text { UT } \\
\text { background }\end{array}$ \\
\hline Time (s UTC) & 58310 & 58350 \\
\hline Altitude (km) & 14.4 & 14.7 \\
\hline Pressure (hPa) & 133 & 127.2 \\
\hline$T(\mathrm{~K})$ & 201 & 200.5 \\
\hline$T_{\text {potential }}(\mathrm{K})$ & 358 & 362 \\
\hline $\mathrm{RH} i(\%)$ & 80 & 38 \\
\hline$f_{\text {non volatile }}(\%)$ & 5.9 & 46 \\
\hline $\mathrm{CO}_{2}(\mu \mathrm{mol} \mathrm{mol}-1)$ & 375 & 380 \\
\hline
\end{tabular}

cloud particle number densities (in brown). The occurrence of an NPF between $58200 \mathrm{~s}$ UTC and $58350 \mathrm{~s}$ UTC can be inferred from the four coloured, dotted lines of COPAS data for $N_{\text {aerosol }}$. The absolute number of particles with sizes above $6 \mathrm{~nm}$ (as depicted with the grey dotted line) is unusually high. The number density difference $N_{6-15}$ (yellow dotted line) exceeds 900 particles per $\mathrm{cm}^{3}$ during this flight segment. This is the case inside the cloud patch but also, and more pronounced, in the peak outside of the cloud around $58325 \mathrm{~s}$ UTC. The other coloured dotted lines of additional COPAS data show mostly non-zero differences also for $N_{6-10}$ and $N_{10-15}$ (green and red dotted lines). The existence of particles in these two "size channels" is indicative of coagulation forming larger particles out of the initially nucleated small sizes. Further details together with model calculations are discussed in Weigel et al. (2011). Before the cloud encounter and especially at the strong peak afterwards (around $58325 \mathrm{~s}$ UTC) $N_{10-15}$ is larger, which indicates that a higher fraction of the freshly nucleated particles has grown to sizes beyond $10 \mathrm{~nm}$. For the whole flight segment shown in Fig. 9 we inspected the COPAS internal housekeeping data (e.g., flow rates, stability of temperature settings etc.) with particular care in order to identify possible instrumental artefacts. However, COPAS operated well during this flight segment and we conclude that the M-55 Geophysica had indeed encountered an NPF event. The low mixing ratios concurrently measured for $\mathrm{CO}_{2}$ indicate that both, NPF and cloud event occurred inside an MCS outflow.

From the abscissa for the covered flight distance in Fig. 9 it can be seen that the horizontal scale of the NPF peak between $58310 \mathrm{~s}$ UTC and $58350 \mathrm{~s}$ UTC was quite small (roughly $6 \mathrm{~km}$ ). Also its vertical extent is only $300 \mathrm{~m}$. During these forty seconds flight time the $\mathrm{CO}_{2}$ had increased towards the typical UT/LS background levels. The additional data summarised in Table 3 provide evidence that two adjacent layers of very different properties were stacked upon each other here. The upper layer was dry (with $\mathrm{RH} i<38 \%$ ) and accomodated a non-volatile fine particle fraction of $50 \%$, while the lower layer contained more water vapour ( $\mathrm{RH} i$ of $80 \%$ ) 


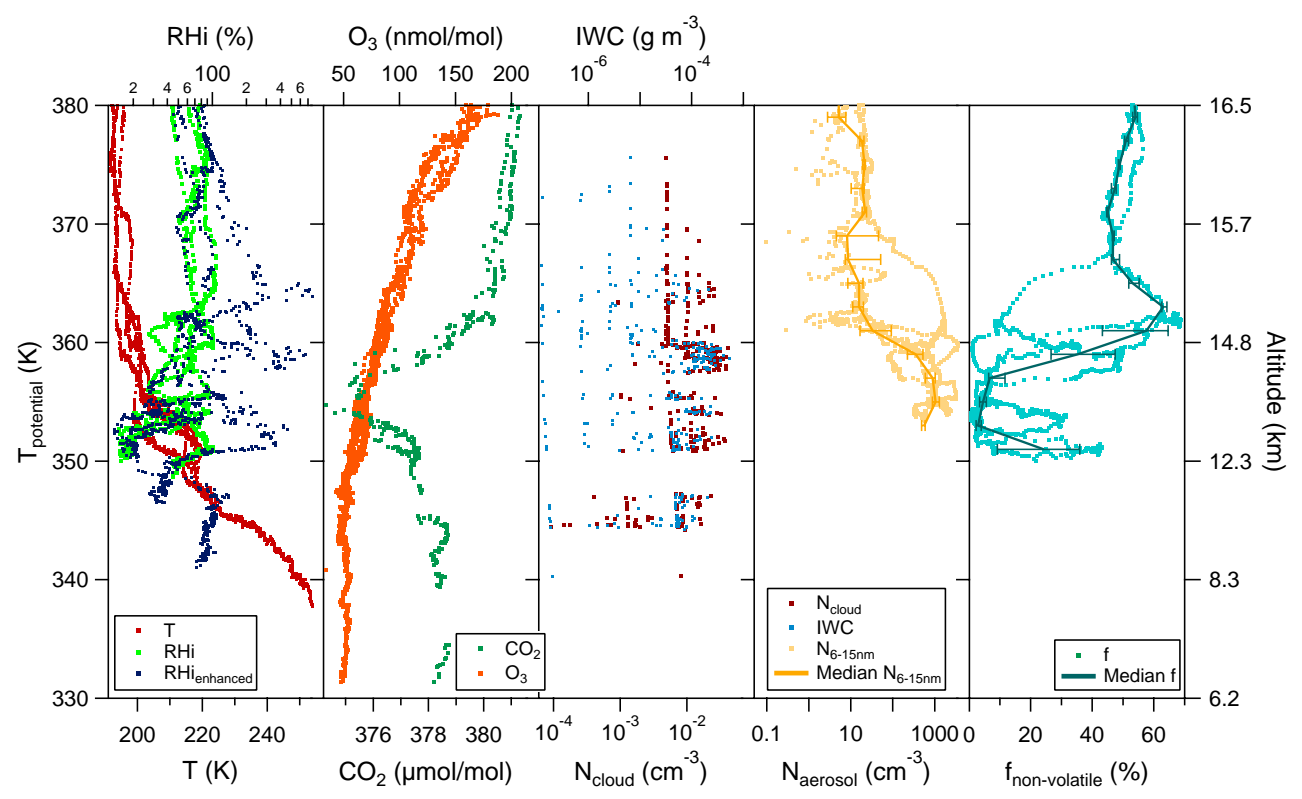

Fig. 8. Vertical profiles of the in situ measurements from the M-55 Geophysica flight on 11 August 2006 during selected flight segments. The error bars in the two rightmost panels denote the 33 and 67 percentiles. The deviations within the measured parameters are a result of the fact that these measurements comprise several ascents/descents including dives within the flight.

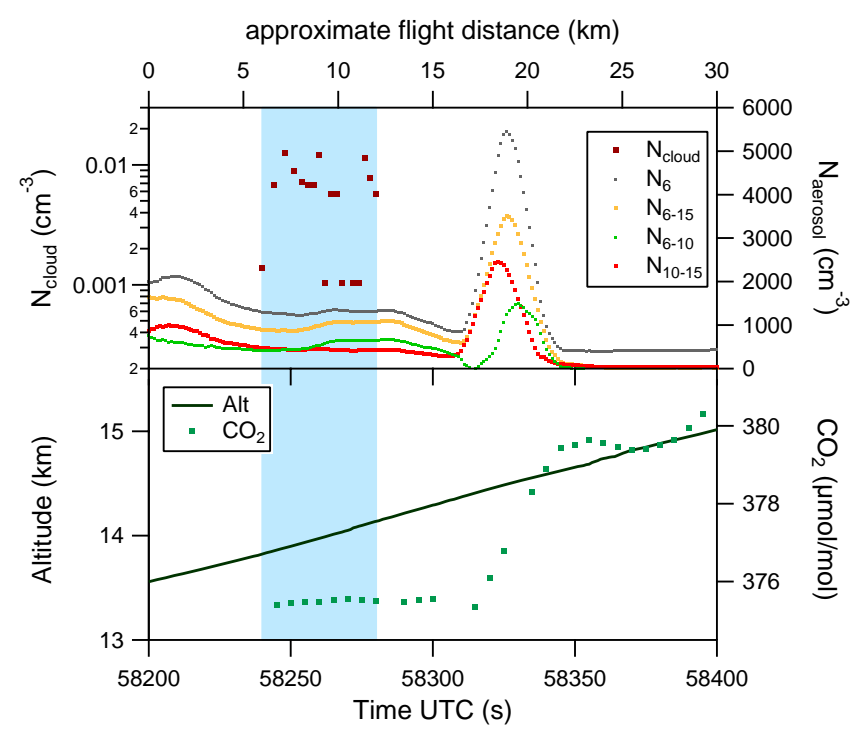

Fig. 9. Segment of the flight time series recorded on 11 August 2006. The blue shading indicates one of the aged outflow events encountered during this flight.

and only $6 \%$ (or less) of the fine aerosol particles were nonvolatile. Since the lower layer constituted the aged MCS outflow air the values listed in the table indicate that entrainment and mixing might have been proceeding concurrently creating a supersaturated environment for binary sulphuric acidwater solution droplets and initiating the peak in the NPF.
Without detailed modelling such considerations remain speculative and other processes may be the cause for the observations. However, the possibility of mixing induced new particle formations on larger scales was pointed out by Khosrawi and Konopka (2003).

\subsubsection{Cloud particle observations within the aged MCS outflow}

The particle size distribution of the cloud crossing is shown in Fig. 10 in the lower left panel. Obviously, the cloud particles were much smaller and fewer than those in the young outflow of Case Study 1 (see Fig. 5). As the relative humidities during this event were below $100 \%$ the cloud patch of this outflow was dissipating. The other cloud particle size distributions given in Fig. 10 in the upper panels are from similar cloud crossings of the same MCS in different outflow locations which were somewhat closer to the squall line. In addition the lower right panel displays further measurements of size distributions (blue lines) from above and below the outflow. Again, in general only small ice particles were detected in very low number concentrations. However, the cloud particles outside of the outflow zones were somewhat larger than inside.

\subsection{Case study 3: cross section through MCS anvil of $7 \mathbf{~ k m}$ thickness}

On the ascent on 16 August 2006 the anvil of an MCS of roughly $400 \mathrm{~km}$ in diameter has been probed (see Fig. 11). The anvil cloud has been observed up to an altitude of 

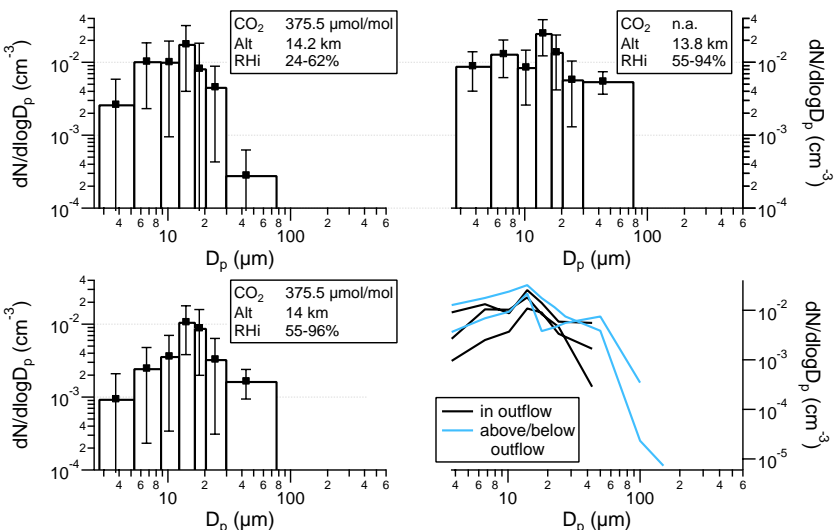

Fig. 10. Comparison of cloud particle size distributions from above, inside and below the aged outflow on 11 August 2006. The three black curves in the lower right panel show the single size distributions of the other panels for a better comparison along with one size distribution from a higher and one from a lower level than the outflow.

$15.1 \mathrm{~km}$ which corresponds to $363 \mathrm{~K}$ potential temperature. The distance to the core region of the MCS was estimated from the satellite image to about $300 \mathrm{~km}$. No tracer measurements are available for the lowest $7.8 \mathrm{~km}$ of the cloud. The level of main MCS outflow is expected at higher altitudes and here measurements of $\mathrm{CO}_{2}, \mathrm{NO}$, and $\mathrm{NO}_{\mathrm{y}}$ are available, as presented in the vertical profiles of Fig. 12. Based on the temperature and ozone measurements the cold point tropopause was found at $15.4 \mathrm{~km}$ altitude and $366 \mathrm{~K}$ potential temperature. Since FLASH data were not available for this flight, the FISH total water content was used to calculate $\mathrm{RH} i_{\text {enhanced }}$, as for the flight on 11 August. Cloudy parts thus show a clear enhancement from the gas phase baseline in the relative humidity. In the altitude band between $348 \mathrm{~K}$ and $362 \mathrm{~K} \mathrm{NO}$ and $\mathrm{NO}_{\mathrm{y}}$ mixing ratios are elevated as well as $\mathrm{CO}_{2}$ mixing ratios are reduced which provides evidence for having encountered a convective outflow region. This is supported by trajectories which indicate an outflow age of around five hours (Fierli et al., 2011). Remarkably, the $\mathrm{O}_{3}$ shows a small maximum in the altitude band between $342 \mathrm{~K}$ and $348 \mathrm{~K}$. Since no correlation to $\mathrm{NO}$ or $\mathrm{NO}_{\mathrm{y}}$ can be found here, these enhanced ozone mixing ratios did not result from the recent outflow event and concurrent photochemical production but could be due to downwind production of $\mathrm{O}_{3}$ from lightning $\mathrm{NO}_{\mathrm{x}}$ emissions produced by an MCS upwind or due to uplift of soil $\mathrm{NO}_{\mathrm{x}}$ emissions which are more elevated over the northern Sahel region (Barret et al., 2010).

A closer look on the cloud crossing in the time series of the ascent in Fig. 13 reveals that the cloud can be divided into three parts. The first part reaches from the ground to $4.8 \mathrm{~km}$ altitude. Here, only particles smaller than $20 \mu \mathrm{m}$ were observed by the FSSP-100 while the CIP showed no counts (see the size distribution in the upper left in Fig. 14). These could

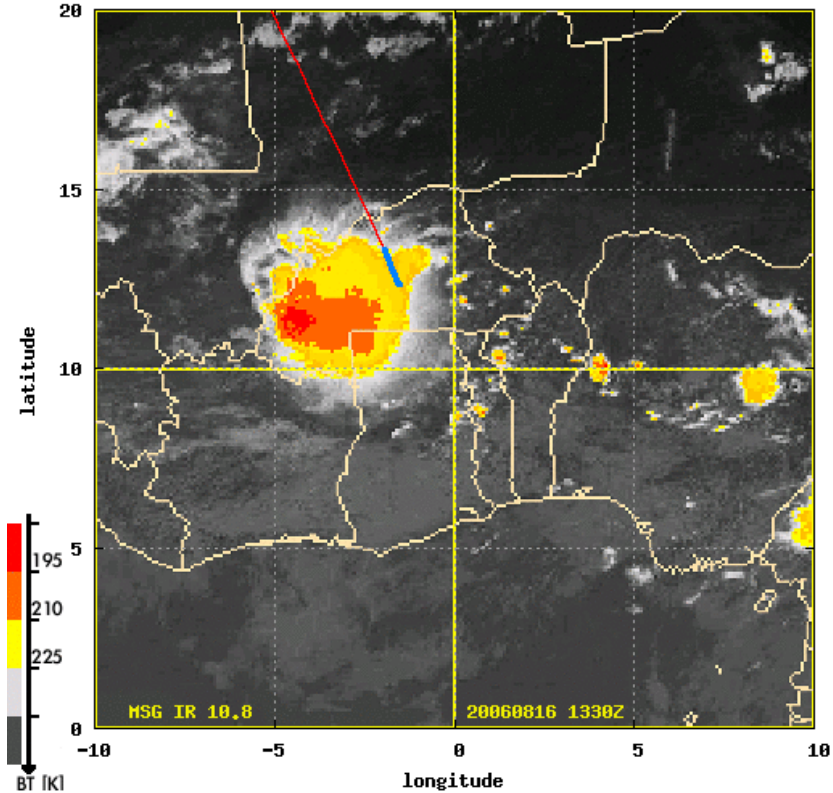

Fig. 11. MSG satellite image of the MCS on 16 August 2006 with the flight track of the M-55 Geophysica as indicated in blue/red.

be remnants of evaporating precipitation, haze droplets or large aerosol particles. The latter could either be resuspended from the ground by the gust fronts or grown to size by water uptake. Also the Colour Index (CI), defined from the MAS backscattering measurements at $1064 \mathrm{~nm}$ and $532 \mathrm{~nm}$ (as in Liu and Mishchenko, 2001), gives high values in this layer, indicating scattering predominantly from larger aerosol particles. The second cloud layer extended from $5.7 \mathrm{~km}$ to $10.6 \mathrm{~km}$ (between the two local minima of the cloud particle number concentration in Fig. 13). The abrupt change in $\mathrm{CI}$ indicates the presence of a different type of cloud particles which are much larger as indicated by the low CI values. At the lower part of this layer the CIP imaged very large ice cloud particles as snow flakes and aggregates. A few examples are shown in Fig. 15. Since the ambient temperatures in this cloud part varied from $-7{ }^{\circ} \mathrm{C}$ to $-41^{\circ} \mathrm{C}$, the presence of liquid cloud droplets, detected by the FSSP-100, cannot be ruled out completely. However, the aerosol depolarisation measurements do give no indication for a large presence of cloud droplets. Tracer measurements are not available during the first part of the layer crossing. Towards the end of the encounter $\mathrm{CO}_{2}$ mixing ratios were rather high and $\mathrm{NO}$ mixing ratios low which implies that there was no outflow. The third cloud layer between $10.6 \mathrm{~km}$ to $15.1 \mathrm{~km}$ altitude contained outflow signatures in the tracer data. As evident from the size distribution in the lower left of Fig. 14 again only small particles were detected by the FSSP-100 at the end of this layer. Further size distributions of selected time periods, as shaded in blue in Fig. 13, are displayed in Fig. 14. Two of the displayed size distributions were measured below the outflow 


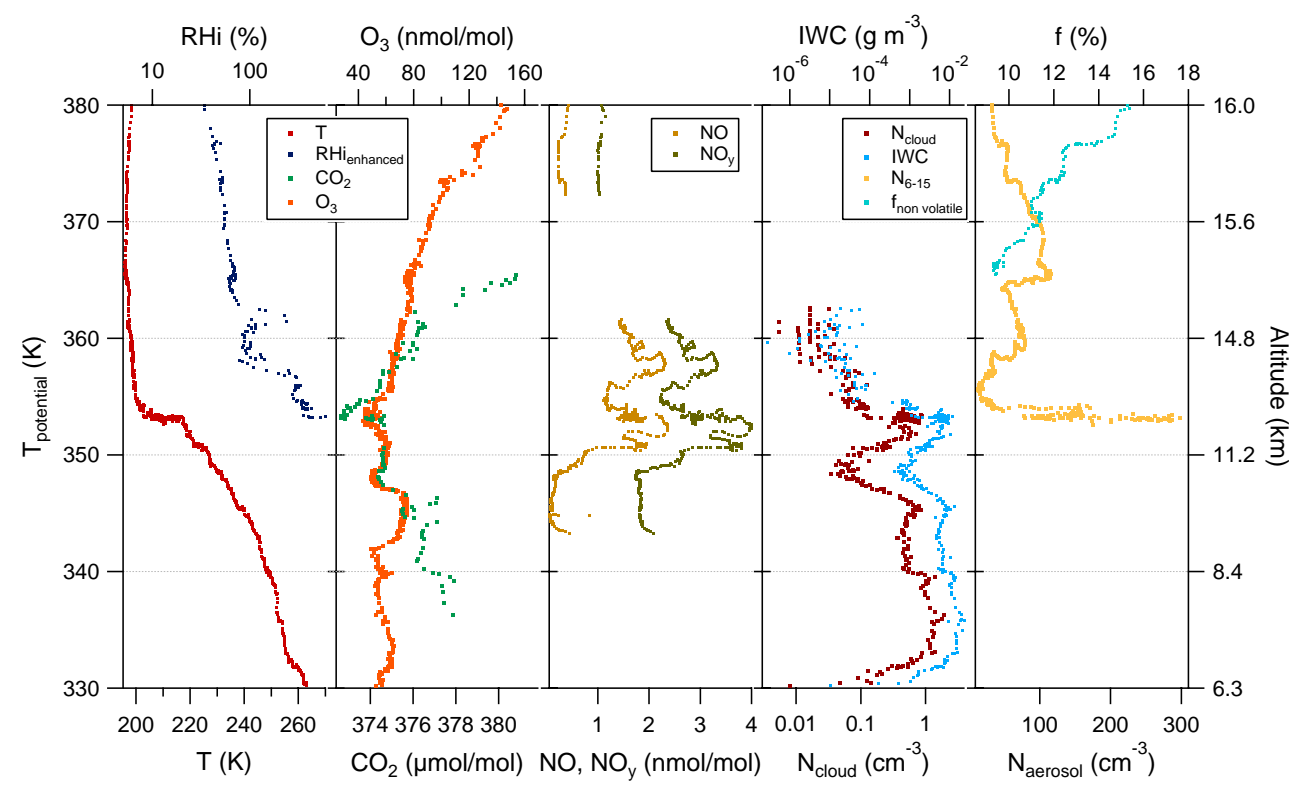

Fig. 12. Vertical profiles recorded by the M-55 Geophysica during its ascent from Ouagadougou, Burkina Faso, on 16 August 2006.

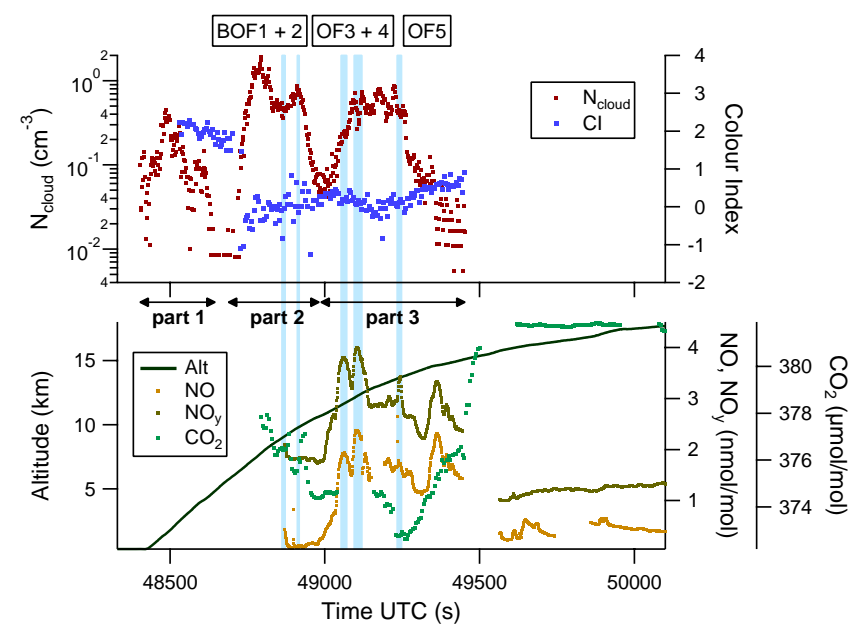

Fig. 13. Time series showing the ascent through the MCS anvil on 16 August 2006. The shading indicates time periods which were selected for deriving the ice particle size distributions from Fig. 14. (See text for details.)

in the second cloud part ("BOF1" and "BOF2") and three inside the outflow region ("OF3" to "OF5"). In general, the outflow size distributions show similar values for the number densities, only the maximum particle sizes decrease slightly with altitude. In comparison to the young outflow event on 7 August the size distributions from 16 August show similar but somewhat lower concentrations and sizes. However, a clear difference to the aged outflow events of 11 August is obvious. Considering the satellite picture and the distance to the MCS core region, the event of 16 August was a recent
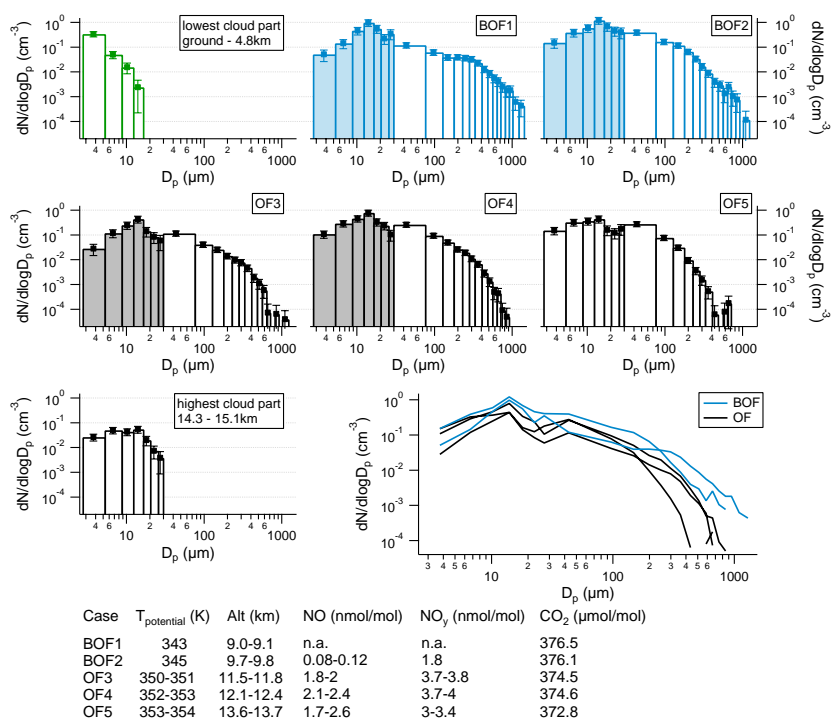

Fig. 14. Selected size distributions from the ascent on 16 August 2006 along with altitude and tracer mixing ratio information. The blue size distributions are compiled from measurements below the outflow ("BOF1" and "BOF2") and the black ones inside the outflow. The lower right panel summarises the ice particle size distributions from below and inside the outflow for comparison. The particle size distributions of the lowest and highest cloud parts are measured by the FSSP-100 only. The shading in the FSSP-100 size range indicates potential shattering contamination.

outflow. The difference between the $\mathrm{NO}$ and $\mathrm{NO}_{\mathrm{y}}$ mixing ratios is larger than for the young outflow of 7 August which indicates that parts of the NO had already been oxidised. A 


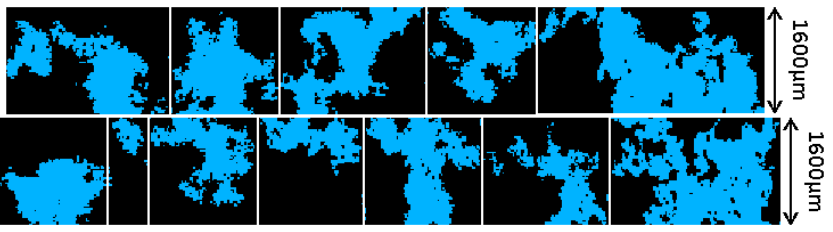

Fig. 15. Examples of CIP shadow images as observed at roughly $6 \mathrm{~km}$ altitude during the 16 August flight.

Table 4. Summary of the microphysical parameters of the four West African SVC cases in August 2006. The parameters include effective radius $\left(r_{\text {eff }}\right)$, number concentrations for cloud particles $\left(N_{\text {cloud }}\right.$, larger $2.7 \mu \mathrm{m})$ and aerosol particles $\left(N_{\text {aerosol }}\right.$, larger $\left.15 \mathrm{~nm}\right)$, aerosol volume backscatter coefficient $(B a)$, and aerosol depolarisation ratio $(D a)$

\begin{tabular}{lcccc}
\hline & SVC1 & SVC2 & SVC3 & SVC4 \\
\hline$r_{\text {eff }}(\mu \mathrm{m})$ & 2.3 & 20.9 & 20.4 & 5.8 \\
IWC $\left(\mathrm{g} \mathrm{m}^{-3}\right)$ & $0.3 \times 10^{-5}$ & $15 \times 10^{-5}$ & $38 \times 10^{-5}$ & $1.7 \times 10^{-5}$ \\
$N_{\text {cloud }}\left(\mathrm{cm}^{-3}\right)$ & $2 \times 10^{-3}$ & $9 \times 10^{-3}$ & $24 \times 10^{-3}$ & $7 \times 10^{-3}$ \\
$N_{\text {aerosol }}\left(\mathrm{cm}^{-3}\right)$ & 408 & 479 & 776 & 302 \\
RH $i(\%)$ & 130 & 86 & n.a. & 94 \\
$T(\mathrm{~K})$ & 192 & 195 & 198 & 195 \\
$B a\left(\mathrm{~m}^{-1} \mathrm{sr}^{-1}\right)$ & $6.6 \times 10^{-8}$ & $1.3 \times 10^{-7}$ & $1.7 \times 10^{-7}$ & $1.1 \times 10^{-7}$ \\
$D a(\%)$ & 28 & 45 & n.a. & 63 \\
$\tau$ & n.a. & 0.0055 & 0.0102 & 0.0051 \\
\hline
\end{tabular}

conclusion could be that the outflow air of 16 August had undergone longer chemical processing than on 7 August.

\subsection{In situ measurements of subvisual cirrus over West Africa}

Only few in situ measurements of cloud particle size distributions inside subvisual cirrus (SVC) are reported in the literature. Those measurements originate from the tropical West Pacific in 1973 (Heymsfield, 1986; McFarquhar et al., 2000); the Indian Ocean during APE-THESEO in 1999 (Luo et al., 2003a,b; Peter et al., 2003; Thomas et al., 2002); the Meso American Pacific during CRAVE, 2006, (Lawson et al., 2008); and from the equatorial Eastern Pacific during TC4 in 2007 (Davis et al., 2010). The measurements presented here are the first data of this kind obtained over West Africa. These extend the known data set of tropical SVC and also contribute continental measurements while the other observations were from maritime regions.

During the research flights of SCOUT-AMMA four subvisual cirrus clouds were encountered close to the tropopause and within the TTL over West Africa. The detailed size distributions compiled from these events (denoted as SVC1 to SVC4) are displayed in Fig. 16 with the measured microphysical parameters summarised in Table 4 . From the mean microphysical parameters and the vertical extent of the SVC cases SVC2, SVC3, and SVC4 a rough estimate of the op-
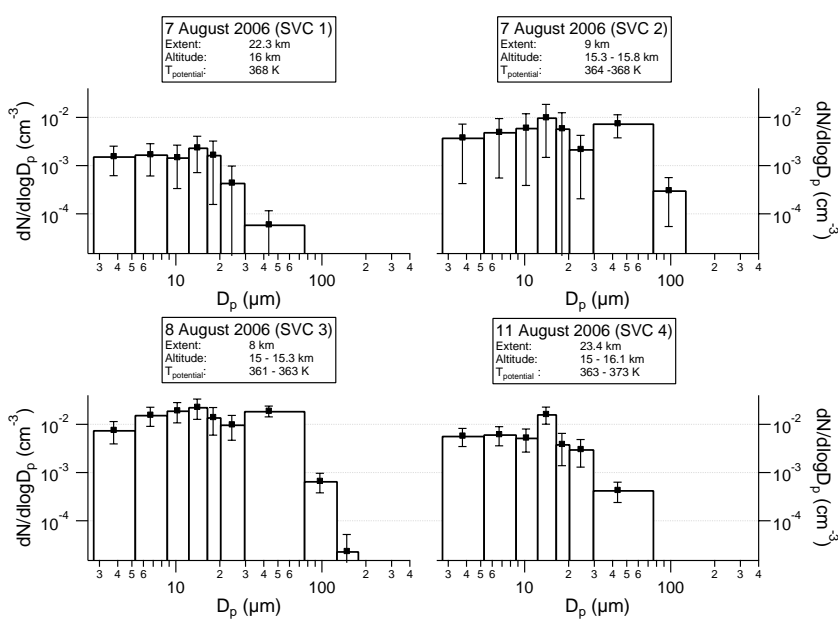

Fig. 16. Subvisual cirrus (SVC) ice particle size distributions (combined FSSP-100 and CIP in situ data) from 7, 8, and 11 August 2006 over West Africa. The horizontal extent was estimated from flight time intervals. The local cold point tropopause height was $16.3 \mathrm{~km}$ on 7 August 2006 and $16.5 \mathrm{~km}$ on the other days. The error bars result from uncertainties in the sampling volumes and counting statistics.

tical thickness $(\tau)$ can be obtained following Garrett et al. (2003):

$\tau=\Delta z \beta=\Delta z \frac{3 \mathrm{CWC}}{2 \rho r_{\mathrm{eff}}}$,

where $\Delta z$ is the vertical cloud thickness, $\beta$ the extinction coefficient, CWC the condensed water content, which is in the SVC cases equal to the IWC, $\rho$ the density of ice, and $r_{\text {eff }}$ the effective radius. Since SVC1 has been probed on level flight, no estimate of the vertical cloud thickness can be made and thus no estimate about $\tau$ can be provided. The estimation of $\tau$ for SVC2, SVC3, and SVC4 results in 0.0055, 0.0102, and 0.0051 , respectively and thus $\tau$ is below the threshold of 0.03 for subvisual cirrus as defined by Sassen and Cho (1992). Since the IWC of SVC1 is smaller than the IWC of the other events it can be assumed that the optical thickness also is subvisual.

The duration of the cloud encounters (i.e. averaging time for the size distributions) ranged between $52 \mathrm{~s}$ and $143 \mathrm{~s}$, the clouds were observed in altitudes between $15 \mathrm{~km}$ and $16.1 \mathrm{~km}$, and at potential temperatures between $361 \mathrm{~K}$ and $373 \mathrm{~K}$. The local cold point tropopause on these days was located at about $16.3 \mathrm{~km}$ altitude on 7 August 2006 and at about $16.5 \mathrm{~km}$ altitude on 8 and 11 August 2006. Thus, the subvisual clouds were observed a few hundred meters below the tropopause. The lowest temperature inside the SVCs was observed during the encounter of SVC1 (192 K) which also had the lowest number concentration and IWC. The warmest cloud was SVC3 with temperatures of $197 \mathrm{~K}$ and here, the highest number concentrations and largest IWC 
were detected. Although the difference between these temperatures is not large, the corresponding saturation vapour pressures with respect to ice differ by a factor of 2.7 which influences the capability of the clouds for freeze-drying the air ascending through them. (For comparison, the temperatures observed for the SVC by Lawson et al. (2008) were between $183 \mathrm{~K}$ and $198 \mathrm{~K}$, by Davis et al. (2010) between $193 \mathrm{~K}$ and $198 \mathrm{~K}$, and by Thomas et al. (2002) between $192 \mathrm{~K}$ and 197 K.)

None of the observed ice particles is larger than $130 \mu \mathrm{m}$ in diameter and during none of these events the CIP detected any shattering. Therefore, it is unlikely that the FSSP-100 measurements inside these SVC are noticeable affected by shattering. The CIP measurements cannot distinguish particle shapes because too few pixels are shaded in the $25 \mu \mathrm{m}$ resolution. However, Lawson et al. (2008) and Davis et al. (2010) analysed the shapes of the tropical SVC particles observed by a Cloud Particle Imager (CPI) and found primarily quasi-spherical particles and some plate-like hexagonal particles (Lawson et al., 2008). Furthermore, columnar and trigonal particle shapes have been observed with a replicator (McFarquhar et al., 2000; Heymsfield, 1986). Although no direct shape measurements are available for the SCOUT-AMMA SVCs, the MAS aerosol depolarisation ratio and Colour Index measurements give some observational information of the ice particle morphology: while the aerosol depolarisation ratio showed medium to high values $(40-100 \%)$ in the outflow events, medium values (28-63\%) were observed in the SVC encounters. Similarly, the Color Index was small within the outflow, and slightly increased with altitude and in the SVCs. These observations suggest large depolarising particles in the MCS outflows. By contrast, the SVCs seem to have more of smaller particles that possibly have a different morphology than those inside the outflows. Thus, the observed CIP shadow images within the outflows, which were irregularly shaped ice crystals like aggregates, and the former SVC shape observations, which were mostly quasispherical, are in good qualitative agreement with the MAS observations. Under these circumstances (i.e., the absence of highly aspherical small ice crystals) particles smaller than roughly $16 \mu \mathrm{m}$ can be reliably sized by the FSSP-100 (Borrmann et al., 2000). For the particles above $25 \mu \mathrm{m}$ the CIP image analyses were applied as described above. Thus, between $16 \mu \mathrm{m}$ and $25 \mu \mathrm{m}$ some uncertainty remains with respect to the sizing of the potentially aspherical particles by scattered light measurements of the FSSP-100. This may be the reason for the "spike" occasionally found in the fourth size bin in Fig. 16.

In order to relate the West African measurements to the overall picture of available SVC size distribution data, a summarising graph is presented here in the left panel of Fig. 17 which extends the original figure shown in Davis et al. (2010). The events observed during SCOUT-AMMA, represented by the thin coloured lines, generally fit well into the previous data from other regions (thick grey lines) and all size distributions show that there are no particles larger than $200 \mu \mathrm{m}$ inside SVCs.

In the West African SVCs the measured ice crystal number concentrations range between $2 \times 10^{-3} \mathrm{~cm}^{-3}$ and $2.4 \times 10^{-2} \mathrm{~cm}^{-3}$, the IWCs range from $3 \times 10^{-6} \mathrm{~g} \mathrm{~m}^{-3}$ to $3.8 \times 10^{-4} \mathrm{~g} \mathrm{~m}^{-3}$, and the effective radii from $2.3 \mu \mathrm{m}$ to $20.9 \mu \mathrm{m}$. These values are comparable to those obtained from the measurements in the maritime area of Costa Rica during the CRAVE campaign. For example the effective radii reported there lie between $2.44 \mu \mathrm{m}$ and $16.7 \mu \mathrm{m}$ and the IWCs vary from $1.2 \times 10^{-5} \mathrm{~g} \mathrm{~m}^{-3}$ to $50 \times 10^{-5} \mathrm{~g} \mathrm{~m}^{-3}$. The largest sizes found over maritime Middle America were $165 \mu \mathrm{m}$. However, in comparison to the measurements obtained over the West Pacific and during CRAVE the West African observations exhibit concentrations which are more than an order of magnitude lower for particles below $10 \mu \mathrm{m}$. At the same time, the events SVC2 and SVC3 show higher concentrations for particles with sizes larger than $50 \mu \mathrm{m}$ with respect to CRAVE and TC4. Possibly due to the contribution of these large particles the two West African events at the same time have higher IWCs (i.e., of $1.5 \times 10^{-4} \mathrm{~g} \mathrm{~m}^{-3}$ to $3.8 \times 10^{-4} \mathrm{~g} \mathrm{~m}^{-3}$ compared to $5.5 \times 10^{-5} \mathrm{~g} \mathrm{~m}^{-3}$ in CRAVE and $5.6 \times 10^{-6} \mathrm{~g} \mathrm{~m}^{-3}$ in TC4).

Despite such differences in details the size distributions $n_{*}\left(D_{p}\right)$ for tropical SVC from the literature are similar enough to calculate a mathematical fit. The result of an exponential least squares fit, which gave the best result of all tested fit functions, according to

$n_{*}\left(D_{p}\right)=\frac{d N}{d \log D_{p}}=A \cdot \exp \left(-\frac{D_{p}}{\kappa \cdot D_{p 0}}\right)$

is shown in the right panel of Fig. 17. The $d N / d \log D_{p}$ values result in $\mathrm{cm}^{-3}$, if $D_{p}$ is supplied in $\mu \mathrm{m}$. The coefficient $A$ is $0.044422 \pm 0.0123 \mathrm{~cm}^{-3}, \kappa=13.98 \pm 6.08$, and $D_{p 0}=1 \mu \mathrm{m}$ is used to eliminate the unit. As the one-sigma deviation lines in Fig. 17 demonstrate, this simple parameterisation seems to represent the tropical subvisual cirrus cloud size distributions quite well. In order to give an easy understandable estimate of the fit quality, a linear regression on the logarithms of the $n^{*}\left(D_{p}\right)$ has been performed. The resulting Pearson correlation coefficient is $r=-0.89\left(r^{2}=0.79\right)$. Thus, the fit might be useful for large and mesoscale modelling purposes, where the microphysical processes are not resolved and as long as not more data are available in order to formulate a parameterisation.

The size distributions from Fig. 16 exhibit a significant fraction of larger particles with sizes above $50 \mu \mathrm{m}$. This is of significance in the context of the stabilisation mechanism suggested by Luo et al. (2003b), who assumed smaller sized particles. Under the given thermodynamic conditions such large particles $(50-200 \mu \mathrm{m})$ have terminal settling velocities ranging between roughly $10 \mathrm{~mm} \mathrm{~s}^{-1}$ and $1000 \mathrm{~mm} \mathrm{~s}^{-1}$. Thus, as noted by Lawson et al. (2008), the prevailing vertical wind speeds are by far too small to lift these particles and 

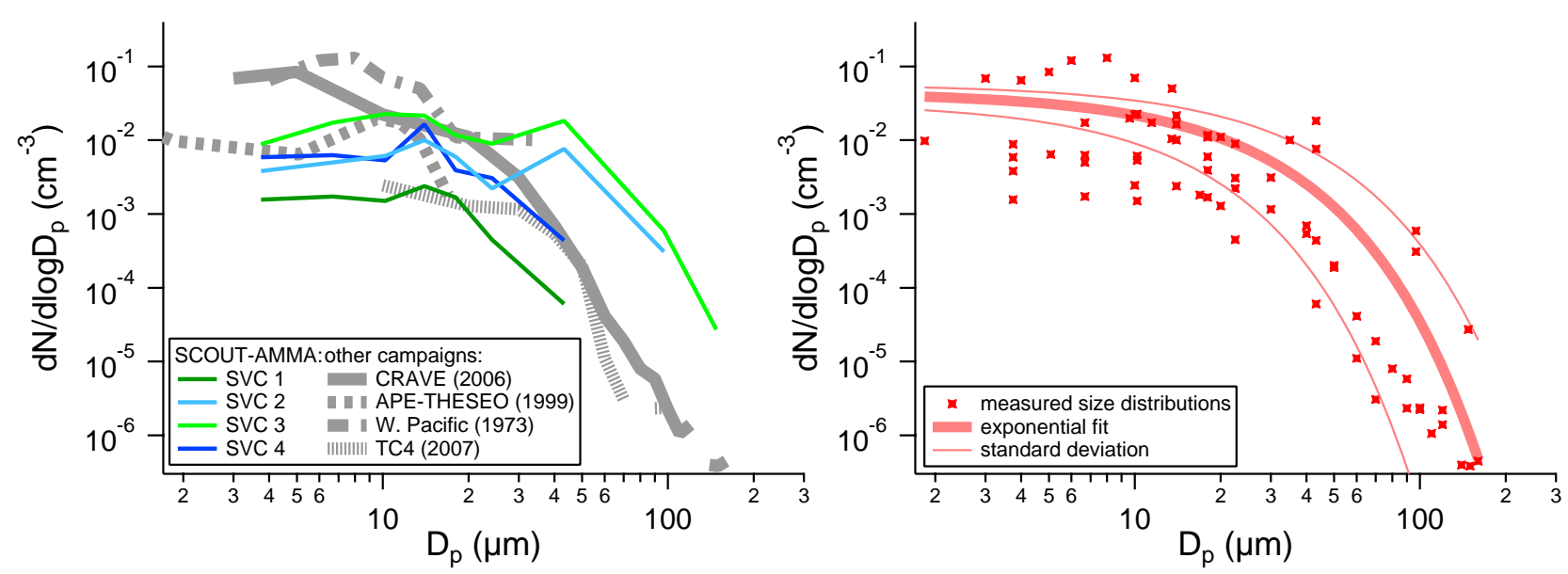

Fig. 17. Left panel (adapted from Davis et al., 2010): overview of in situ measurements for tropical SVC. The observations obtained during the indicated previous field experiments are shown in broad grey lines. The coloured lines depict the individual cloud encounters from SCOUT-AMMA in West Africa. Right panel: an exponential fit was derived from all size distributions in the left panel with one sigma deviations. See Eq. (3) for the fit equation and coefficients.

therefore, extended SVCs containing such large particles can not be maintained by this mechanism.

Due to the lack of concurrent LIDAR observations for the measurements in West Africa the horizontal extent of these SVCs is not known (unlike e.g. for the APE-THESEO case where the cloud sheet covered roughly $250 \mathrm{~km}$ ). This implies that either the clouds were more localised with transient atmospheric conditions allowing for their existence, or the vertical wind velocities in the field of the propagating MCS were locally high enough to support larger ice particles. The subvisual clouds during SCOUT-AMMA were observed in a region influenced by strong convection and thus, might have formed as remnants of convective anvils. However, the tracer measurements obtained at the same time did not show any convective signatures. Either the time past the convection was long enough such that the air had mixed with surrounding air diminishing the convective signature, or the SVC had formed in situ. Both mechanisms are recognised in the literature (e.g. McFarquhar et al., 2000; Pfister et al., 2001; Massie et al., 2002).

\subsection{Interstitial aerosol number densities in SVC and MCS}

In order to obtain an estimate of how many cloud particles result from activation of the present aerosol, it is instructive to plot the COPAS measurements as proxy for the available aerosol particle number densities versus the concurrently measured cloud particle number concentration. Since the number of cloud particles (partly also detected by COPAS) is much smaller than the submicron aerosol number densities, the contribution of the cloud particles to $N_{6}, N_{10}$, $N_{15}$ can be considered as small or negligible. This especially holds for the encountered upper tropospheric clouds because the ice particles are for the most part much larger than $1 \mu \mathrm{m}$ which roughly is the upper particle size which the COPAS inlet is able to aspirate with proper efficiency. In Fig. 18 the results from the SVCs and the MCS outflows from West Africa (SCOUT-AMMA) are juxtaposed with data from the Hector MCS in Northern Australia (SCOUT-O3; see de Reus et al., 2009). (The Hector storm system is a very intense MCS which forms over the Tiwi Islands, north of Darwin, Australia, during the premonsoon season and monsoon breaks, Crook, 2001; Connolly et al., 2006.) Although the data base is small, the three different cloud environments can be clearly discerned. For the SVCs (which are described in Sect. 4.5) we found roughly one cloud ice particle per 30000 detected aerosol particles. This is in agreement with the results from Jensen et al. (2010) who derived from model calculations that only very few aerosol particles can serve as ice nuclei for the activation of cloud particles in SVC. For the MCS outflow cases one cloud particle occurs per $\approx 1000$ aerosol particles with some observations as high as one of 300 . This difference between these numbers of the two cloud types may be indicative of the respective roles which deposition freezing and homogeneous freezing play for cloud formation. It also can be assumed that in the outflow cases all the mechanisms of ice multiplication (collisional multiplication, Hallet Mossop mechanism, splintering, and riming) play a major role. These are absent in SVC which formed ice particles (not larger than $200 \mu \mathrm{m}$ ) mostly by deposition nucleation. The values for the single MCS cluster Hector span the range between one over 30000 and one over 300 with a clustering of points near the 1/3000 ratio line. As the light blue symbols indicate, NPF events could be identified for a few cases of the Hector MCS and also during SCOUT-AMMA. Since the figure only shows the concentration $N_{15}\left(N_{10}\right.$ if $N_{15}$ was 


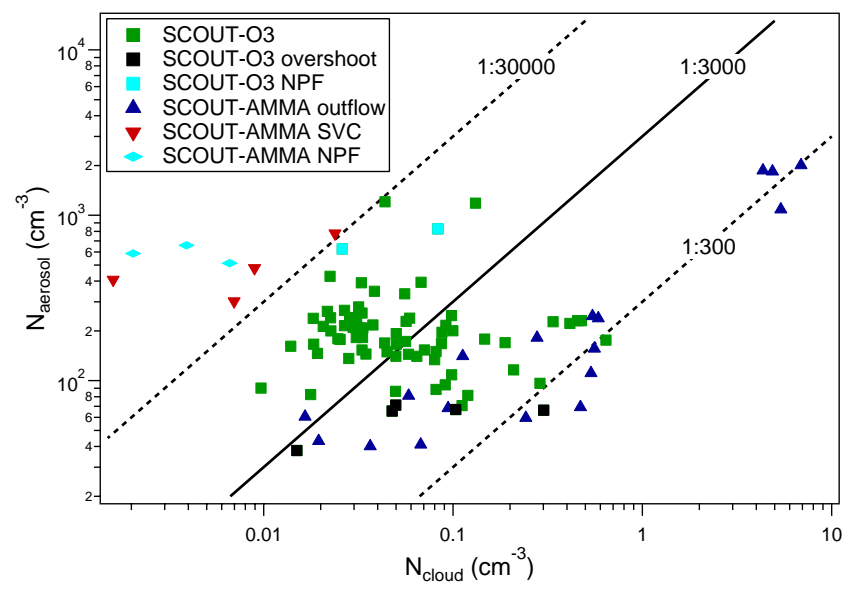

Fig. 18. Interstitial aerosol and cloud particle in situ measurements of tropical cloud encounters in West-Africa (2006) and Northern Australia (2005). The ordinate shows the aerosol particle number concentration (measured by COPAS as proxy for the interstitial aerosol) covering size diameters between $15 \mathrm{~nm}$ (or $10 \mathrm{~nm}$ in a few cases) and roughly $1 \mu \mathrm{m}$. The abscissa gives the simultaneously detected cloud particle number densities for sizes above $2 \mu \mathrm{m}$ as measured by the CIP and FSSP-100 probes. The events are from the Australian Hector MCS (squares), the West African MCS outflows (blue triangles), and the West African SVCs (red triangles). Furthermore, NPF events are indicated in light blue. The lines indicate activation ratios in terms of the numbers of cloud particles and the available aerosol particles.

not available) the absolute numbers are relatively small. The values for $N_{6}$ as concurrently measured by COPAS were between 2000 and $3000 \mathrm{~cm}^{-3}$. Here, the difference between $N_{6}$ and $N_{15}$ is by far large enough for identification as an NPF event. (For the two green squares and the four dark blue triangles with number densities $N_{15}$ above $1000 \mathrm{~cm}^{-3}$ in Fig. 18 no $N_{6}$ data are available or the $N_{6}-N_{15}$ difference was too small for an NPF event.) Based on the few measured points one could speculate that NPF events preferably occur under circumstances where only a few cloud ice particles are present.

These data certainly are only an indirect estimate of the degree of cloud activation for these clouds. As pointed out by de Reus et al. (2009) the original activation ratio may differ from these measurements because there are sinks for particles such as scavenging by deposition on ice particles, washout by supercooled droplets, mixing with the local ambient air, and entrainment of cloud free air. As shown in Sect. 4.1 in-cloud NPF may be a source for ultrafine aerosol (Weigel et al., 2011). Although the very low ratios for the SVC cases indicate that deposition freezing might have formed these, a variety of processes which are not directly related to heterogeneous aerosol ice activation (e.g., homogeneous droplet freezing) may have been involved at varying intensities during the cloud lifetime in particular for the
MCS outflows and Hector. For mid-latitude cirrus Seifert et al. (2004) found a positive correlation between the number concentrations of interstitial aerosols and ice crystals as long as the interstitial particle number densities were below $100 \mathrm{~cm}^{-3}$ and at higher aerosol concentrations a negative correlation was measured.

Despite such considerations the measurements in Fig. 18 provide data as boundaries for modelling purposes which may help to estimate the contributions of the different microphysical processes.

\section{Summary and conclusions}

In situ observations of cloud ice particle properties have been obtained in the vicinity of MCS and within the tropical UT/LS at the time of the West African Monsoon during the SCOUT-AMMA campaign in Ouagadougou, Burkina Faso, in 2006. These data provide a contribution to the very sparse data set of in situ measurements of MCS outflows and tropical SVC above an important continental area.

The observed ice crystal size distributions show a decrease in maximum particle size when ascending to the tropopause region. However, compared to observations from SCOUT$\mathrm{O} 3$ and size distributions derived from CEPEX parameterisation, both experiments over maritime regions, the SCOUTAMMA observations show clearly larger particles as well as a higher fraction of large particles. This may be indicative of the presence of larger hydrometeors in MCSs over continental regions compared to those over maritime regions, as also suggested by Cetrone and Houze (2009). Two to four modal lognormal size distributions have been fitted to the West African measurements for each potential temperature bin in oder to provide a mathematical description of the continental MCS size distributions.

Trace gas observations, satellite images, and trajectory analysis were used to identify MCS outflow events and to estimate the age of those events. Clouds within young outflow events were sampled on two flights, one resulting from a newly developing system and the other from a mature system. The particle images show heavily rimed ice particles or rimed aggregates with sizes even extending beyond $1.6 \mathrm{~mm}$ (i.e. the maximum size of the CIP images across the diode array). Ice crystal number concentrations of up to $8.3 \mathrm{~cm}^{-3}$ and IWCs of up to $0.05 \mathrm{~g} \mathrm{~m}^{-3}$ were observed, the effective radius was about $90 \mu \mathrm{m}$. In contrast to this, clouds within aged outflow events reveal much smaller values. Here, maximum concentrations of $0.03 \mathrm{~cm}^{-3}$, IWCs of up to $2.3 \times 10^{-4} \mathrm{~g} \mathrm{~m}^{-3}$, and an effective radius of about $18 \mu \mathrm{m}$ have been found with particles reaching a maximum dimension of $61 \mu \mathrm{m}$. The size distributions of all outflow events show a clear decrease in maximum particle sizes and number concentrations with age which is displayed in Fig. 19. The snap-shots of consecutive CIP particle images, as shown on top of the figure, underscore the change in size 


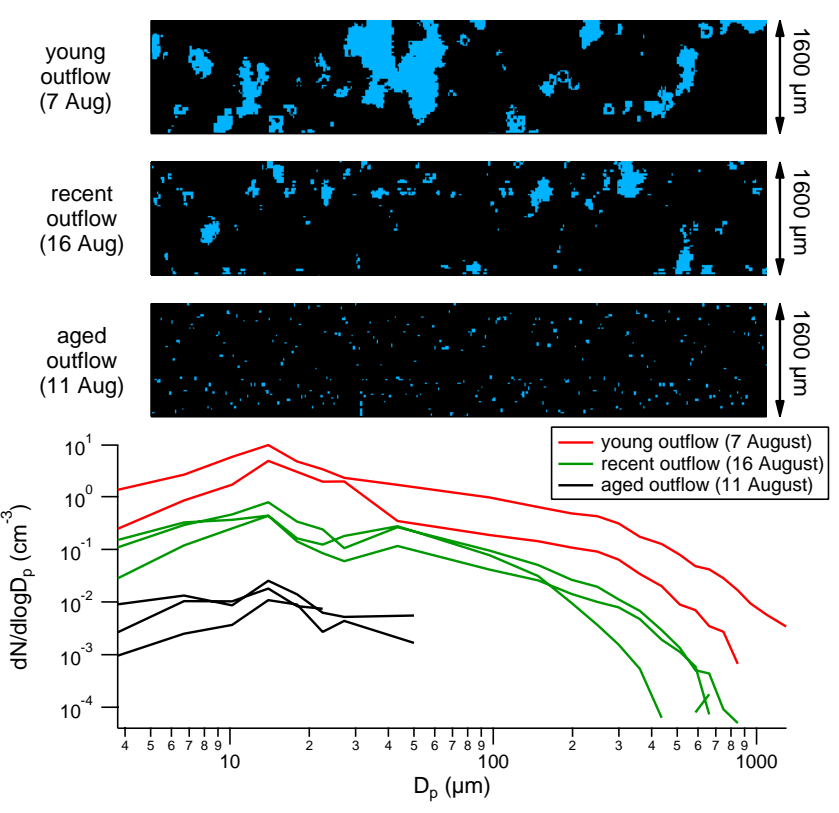

Fig. 19. Summary of outflow size distributions of the three flights on 7, 11, and 16 August 2006. Additionally, examples of consecutive CIP particle images for each outflow age are displayed on top starting with the youngest case.

with age. Furthermore, the outflow altitude increases with age. This is supported by Houze (1989) who describes the upward transport of older convective cells within an MCS.

Besides the measurements connected to MCS outflows four encounters of subvisual tropopause cirrus have occurred at altitudes between $15-16.1 \mathrm{~km}$, which corresponds to a distance to the tropopause of $300-600 \mathrm{~m}$. These observations extend the existing data set of tropical SVC and constitute the first continental SVC measurements. The largest particles had sizes of up to $130 \mu \mathrm{m}$, while the number concentrations ranged from $2 \times 10^{-3} \mathrm{~cm}^{-3}$ to $24 \times 10^{-3} \mathrm{~cm}^{-3}$, IWCs from $0.3 \times 10^{-5} \mathrm{~g} \mathrm{~m}^{-3}$ to $38 \times 10^{-5} \mathrm{~g} \mathrm{~m}^{-3}$, and the effective radii varied between $2.3 \mu \mathrm{m}$ and $20.9 \mu \mathrm{m}$. The size distributions of the SVC events are compared to all so far known SVC size distributions and an exponential fit on all of these is calculated. We provide this mathematical description of SVC for modelling studies which is important since they play an important role in the Earth's radiation budget.

Differences in the aerosol depolarisation ratio and Colour Index observed by MAS between the measurements inside the MCS outflow clouds and the SVC were found which is indicative of a different ice particle morphology in these two cloud types.

Two cases of New Particle Formation events were encountered inside of ice clouds close to or in an MCS outflow. While during one event the ice particle number concentrations were low, the other case showed that the NPF event is quenched when ice particle numbers increase. This agrees with observations by Weigel et al. (2011). The former NPF event peaks with a very high amount of newly formed particles, when approaching the air mass boundary between outflow air and upper tropospheric background air. This peak is possibly a result of entrainment and mixing of those two air masses.

By comparing total aerosol number concentrations to ice particle concentrations estimations of the interstitial aerosol and the activation ratio is given. The separation of deep convective events, SVC events, and NPF events yields a significant difference in the activation ratios. While for the deep convective cases (MCS outflow and convective overshooting as observed during the SCOUT-O3 campaign, see de Reus et al., 2009) one cloud particle occurs roughly per 1000 aerosol particles, in some cases even per 300 aerosol particles, the SVC show just one or even less cloud particles per 30000 aerosol particles. This is in agreement to Jensen et al. (2010) who state that only few aerosol particles will act as very efficient ice nuclei in the formation of SVC. NPF events seem to prefer circumstances where only few cloud particles are present.

We would like to emphasise that high quality in situ measurements in the tropical UT/LS are difficult to obtain since specialised high altitude research aircraft and instrumentation are required in this challenging environment. Thus, also the data set of such observations is small and to provide useful parameterisations of either MCS outflow clouds or SVC including microphysical parameters more measurements are needed.

\section{Supplementary material related to this article is available online at: http://www.atmos-chem-phys.net/11/5569/2011/ acp-11-5569-2011-supplement.pdf.}

Acknowledgements. The SCOUT-O3 and SCOUT-AMMA projects were funded by the European Commission through Contract 505390-GOCE-CT-2004-505390 and the EC Integrated Projects AMMA-EU (Contract no. 004089-2). The M-55 Geophysica campaign was supported by the EEIG-Geophysica Consortium, CNRSINSU, CNES, and EUFAR. Meteosat Second Generation data were provided by the AMMA database (http://aoc.amma-international. org/observation/satellite/) and were processed including the flight tracks by Sylwester Arabas from the University of Warsaw, Poland.

Based on a French initiative, AMMA was built by an international scientific group and funded by a large number of agencies, especially from France, the United Kingdom, the United States, Africa, and - for us - German sources. It has been a beneficiary of a major financial contribution from the European Community Sixth Framework Programme (AMMA-EU). Significant financial support for our activities with the M-55 Geophysica in Australia and Burkina Faso also was supplied by the Max Planck Society.

For the CIP data processing we gratefully acknowledge help from Aaron Bansemer (NCAR, Boulder, Co, USA). For very helpful comments on the manuscript we thank Jasmine Cetrone from the 
University of Washington, Seattle, USA. We thank Stefano Balestri, Ana Alfaro Martinez (ERS), and the pilots, engineers, crew of the M-55 Geophysica. The local authorities, scientists and staff in Ouagadougou (Burkina Faso) were wonderful hosts, and we thank for their amazing hospitality and support during this in many respects challenging campaign in Burkina Faso, which for all of us was a deeply moving life experience. Special thanks are due to Toro Drabo from the University in Ouagadougou. We grateful acknowledge the constructive and helpful comments by Darrel Baumgardner, Grant Allen, and the two anonymous referees.

The service charges for this open access publication have been covered by the Max Planck Society.

Edited by: D. Brunner

\section{References}

Ackerman, T. P., Liou, K. N., Valero, F. P. J., and Pfister, L.: Heating Rates In Tropical Anvils, J. Atmos. Sci., 45, 1606-1623, 1988.

Baker, B. and Lawson, R. P.: Improvement in Determination of Ice Water Content from Two-Dimensional Particle Imagery. Part I: Image-to-Mass Relationships, J. Appl. Meteorol. Clim., 45, 1282-1290, 2006.

Barnes, G.: Severe Convective Storms, vol. 28 of AMS Meteorological Monograph Series, chap. 10: Severe local storms in the tropics, pp. 358-432, AMS, 2001.

Barret, B., Williams, J. E., Bouarar, I., Yang, X., Josse, B., Law, K., Pham, M., Le Flochmoën, E., Liousse, C., Peuch, V. H., Carver, G. D., Pyle, J. A., Sauvage, B., van Velthoven, P., Schlager, H., Mari, C., and Cammas, J.-P.: Impact of West African Monsoon convective transport and lightning NOx production upon the upper tropospheric composition: a multi-model study, Atmos. Chem. Phys., 10, 5719-5738, doi:10.5194/acp-10-57192010, 2010.

Barth, M. C., Stuart, A. L., and Skamarock, W. C.: Numerical simulations of the July 10, 1996, Stratospheric-Tropospheric Experiment: Radiation, Aerosols, and Ozone (STERAO)-Deep Convection experiment storm: Redistribution of soluble tracers, J. Geophys. Res.-Atmos., 106, 12381-12400, 2001.

Barth, M. C., Kim, S.-W., Wang, C., Pickering, K. E., Ott, L. E., Stenchikov, G., Leriche, M., Cautenet, S., Pinty, J.-P., Barthe, Ch., Mari, C., Helsdon, J. H., Farley, R. D., Fridlind, A. M., Ackerman, A. S., Spiridonov, V., and Telenta, B.: Cloud-scale model intercomparison of chemical constituent transport in deep convection, Atmos. Chem. Phys., 7, 4709-4731, doi:10.5194/acp-74709-2007, 2007.

Baumgardner, D., Dye, J. E., Gandrud, B. W., and Knollenberg, R. G.: Interpretation Of Measurements Made By The Forward Scattering Spectrometer Probe (FSSP-300) During The Airborne Arctic Stratospheric Expedition, J. Geophys. Res.-Atmos., 97, 8035-8046, 1992.

Borrmann, S., Luo, B. P., and Mishchenko, M.: Application of the T-matrix method to the measurement of aspherical (ellipsoidal) particles with forward scattering optical particle counters, J. Aerosol Sci., 31, 789-799, 2000.

Borrmann, S., Kunkel, D., Weigel, R., Minikin, A., Deshler, T., Wilson, J. C., Curtius, J., Volk, C. M., Homan, C. D., Ulanovsky, A., Ravegnani, F., Viciani, S., Shur, G. N., Belyaev,
G. V., Law, K. S., and Cairo, F.: Aerosols in the tropical and subtropical UT/LS: in-situ measurements of submicron particle abundance and volatility, Atmos. Chem. Phys., 10, 5573-5592, doi:10.5194/acp-10-5573-2010, 2010.

Brunner, D., Siegmund, P., May, P. T., Chappel, L., Schiller, C., Müller, R., Peter, T., Fueglistaler, S., MacKenzie, A. R., Fix, A., Schlager, H., Allen, G., Fjaeraa, A. M., Streibel, M., and Harris, N. R. P.: The SCOUT-O3 Darwin Aircraft Campaign: rationale and meteorology, Atmos. Chem. Phys., 9, 93-117, doi:10.5194/acp-9-93-2009, 2009.

Buontempo, C., Cairo, F., Di Donfrancesco, G., Morbidini, R., Viterbini, M., and Adriani, A.: Optical measurements of atmospheric particles from airborne platforms: in situ and remote sensing instruments for balloons and aircrafts, Ann. Geophys., 49, 57-64, 2006,

http://www.ann-geophys.net/49/57/2006/.

Cairo, F., Adriani, A., Viterbini, M., Di Donfrancesco, G., Mitev, V., Matthey, R., Bastiano, M., Redaelli, G., Dragani, R., Ferretti, R., Rizi, V., Paolucci, T., Bernardini, L., Cacciani, M., Pace, G., and Fiocco, G.: Polar stratospheric clouds observed during the Airborne Polar Experiment-Geophysica Aircraft in Antarctica (APE-GAIA) campaign, J. Geophys. Res., 109, D07204, doi:10.1029/2003JD003930, 2004.

Cairo, F., Pommereau, J. P., Law, K. S., Schlager, H., Garnier, A., Fierli, F., Ern, M., Streibel, M., Arabas, S., Borrmann, S., Berthelier, J. J., Blom, C., Christensen, T., D’Amato, F., Di Donfrancesco, G., Deshler, T., Diedhiou, A., Durry, G., Engelsen, O., Goutail, F., Harris, N. R. P., Kerstel, E. R. T., Khaykin, S., Konopka, P., Kylling, A., Larsen, N., Lebel, T., Liu, X., MacKenzie, A. R., Nielsen, J., Oulanowski, A., Parker, D. J., Pelon, J., Polcher, J., Pyle, J. A., Ravegnani, F., Rivière, E. D., Robinson, A. D., Röckmann, T., Schiller, C., Simões, F., Stefanutti, L., Stroh, F., Some, L., Siegmund, P., Sitnikov, N., Vernier, J. P., Volk, C. M., Voigt, C., von Hobe, M., Viciani, S., and Yushkov, V.: An introduction to the SCOUT-AMMA stratospheric aircraft, balloons and sondes campaign in West Africa, August 2006: rationale and roadmap, Atmos. Chem. Phys., 10, 2237-2256, doi:10.5194/acp-10-2237-2010, 2010.

Cairo, F., Di Donfrancesco, G., Snels, M., Fierli, F., Viterbini, M., Borrmann, S., and Frey, W.: A comparison of light backscattering and particle size distribution measurements in tropical cirrus clouds, Atmos. Meas. Tech., 4, 557-570, doi:10.5194/amt-4557-2011, 2011.

Cetrone, J. and Houze, R. A.: Anvil clouds of tropical mesoscale convective systems in monsoon regions, Q. J. Roy. Meteorol. Soc., 135, 305-317, 2009.

Chong, M.: The 11 August 2006 squall-line system as observed from MIT Doppler radar during the AMMA SOP, Q. J. Roy. Meteorol. Soc., 136, 209-226, doi:10.1002/qj.466, 2010.

Connolly, P. J., Choularton, T. W., Gallagher, M. W., Bower, K. N., Flynn, M. J., and Whiteway, J. A.: Cloud-resolving simulations of intense tropical Hector thunderstorms: Implications for aerosol-cloud interactions, Q. J. Roy. Meteorol. Soc., 132, 30793106, 2006.

Crook, N. A.: Understanding Hector: The dynamics of island thunderstorms, Mon. Weather Rev., 129, 1550-1563, 2001.

Curtius, J., Weigel, R., Vössing, H.-J., Wernli, H., Werner, A., Volk, C.-M., Konopka, P., Krebsbach, M., Schiller, C., Roiger, A., Schlager, H., Dreiling, V., and Borrmann, S.: Observa- 
tions of meteoric material and implications for aerosol nucleation in the winter Arctic lower stratosphere derived from in situ particle measurements, Atmos. Chem. Phys., 5, 3053-3069, doi:10.5194/acp-5-3053-2005, 2005.

Davis, S., Hlavka, D., Jensen, E., Rosenlof, K., Yang, Q., Schmidt, S., Borrmann, S., Frey, W., Lawson, P., Voemel, H., and Bui, T. P.: In situ and lidar observations of tropopause subvisible cirrus clouds during TC4, J. Geophys. Res.-Atmos., 115, D00J17, doi:10.1029/2009JD013093, 2010.

de Reus, M., Borrmann, S., Bansemer, A., Heymsfield, A. J., Weigel, R., Schiller, C., Mitev, V., Frey, W., Kunkel, D., Kürten, A., Curtius, J., Sitnikov, N. M., Ulanovsky, A., and Ravegnani, F.: Evidence for ice particles in the tropical stratosphere from in-situ measurements, Atmos. Chem. Phys., 9, 6775-6792, doi:10.5194/acp-9-6775-2009, 2009.

Field, P. R., Heymsfield, A. J., and Bansemer, A.: Shattering and Particle Interarrival Times Measured by Optical Array Probes in Ice Clouds, J. Atmos. Ocean. Tech., 23, 1357-1371, 2006.

Fierli, F., Orlandi, E., Law, K. S., Cagnazzo, C., Cairo, F., Schiller, C., Borrmann, S., Di Donfrancesco, G., Ravegnani, F., and Volk, C. M.: Impact of deep convection in the tropical tropopause layer in West Africa: in-situ observations and mesoscale modelling, Atmos. Chem. Phys., 11, 201-214, doi:10.5194/acp-11201-2011, 2011.

Froyd, K. D., Murphy, D. M., Sanford, T. J., Thomson, D. S., Wilson, J. C., Pfister, L., and Lait, L.: Aerosol composition of the tropical upper troposphere, Atmos. Chem. Phys., 9, 4363-4385, doi:10.5194/acp-9-4363-2009, 2009.

Froyd, K. D., Murphy, D. M., Lawson, P., Baumgardner, D., and Herman, R. L.: Aerosols that form subvisible cirrus at the tropical tropopause, Atmos. Chem. Phys., 10, 209-218, doi:10.5194/acp-10-209-2010, 2010.

Fueglistaler, S., Dessler, A. E., Dunkerton, T. J., Folkins, I., Fu, Q., and Mote, P. W.: Tropical tropopause layer, Rev. Geophys., 47, RG1004, doi:10.1029/2008RG000267, 2009.

Garrett, T. J., Gerber, H., Baumgardner, D. G., Twohy, C. H., and Weinstock, E. M.: Small, highly reflective ice crystals in low-latitude cirrus, Geophys. Res. Lett., 30, 2132, doi:10.1029/2003GL018153, 2003.

Garrett, T. J., Dean-Day, J., Liu, C., Barnett, B., Mace, G., Baumgardner, D., Webster, C., Bui, T., Read, W., and Minnis, P.: Convective formation of pileus cloud near the tropopause, Atmos. Chem. Phys., 6, 1185-1200, doi:10.5194/acp-6-1185-2006, 2006.

Haag, W. and Kärcher, B.: The impact of aerosols and gravity waves on cirrus clouds at midlatitudes, J. Geophys. Res.-Atmos., 109, D12202, doi:10.1029/2004JD004579, 2004.

Hall, N. M. J. and Peyrille, P.: Dynamics of the west African monsoon, J. Phys. IV, 139, 81-99, doi:10.1051/jp4:2006139007, 2006.

Heymsfield, A. J.: Ice Particles Observed In A Cirriform Cloud At $83^{\circ} \mathrm{C}$ and Implications For Polar Stratospheric Clouds, J. Atmos. Sci., 43, 851-855, 1986.

Heymsfield, A. J. and Parrish, J. L.: A Computational Technique for Increasing the Effective Sampling Volume of the PMS TwoDimensional Particle Size Spectrometer, J. Appl. Meteorol., 17, 1566-1572, 1978.

Heymsfield, A. J., Lewis, S., Bansemer, A., Iaquinta, J., Miloshevich, L. M., Kajikawa, M., Twohy, C., and Poellot, M. R.:
A General Approach for Deriving the Properties of Cirrus and Stratiform Ice Cloud Particles, J. Atmos. Sci., 59, 3-29, 2002.

Homan, C. D., Volk, C. M., Kuhn, A. C., Werner, A., Baehr, J., Viciani, S., Ulanovski, A., and Ravegnani, F.: Tracer measurements in the tropical tropopause layer during the AMMA/SCOUTO3 aircraft campaign, Atmos. Chem. Phys., 10, 3615-3627, doi:10.5194/acp-10-3615-2010, 2010.

Houze, R. A.: Observed Structure of Mesoscale Convective Systems and Implications For Large-scale Heating, Q. J. Roy. Meteorol. Soc., 115, 425-461, 1989.

Houze, R. A.: Mesoscale convective systems, Rev. Geophys., 42, RG4003, doi:10.1029/2004RG000150, 2004.

Huntrieser, H., Schlager, H., Roiger, A., Lichtenstern, M., Schumann, U., Kurz, C., Brunner, D., Schwierz, C., Richter, A., and Stohl, A.: Lightning-produced $\mathrm{NO}_{\mathrm{x}}$ over Brazil during TROCCINOX: airborne measurements in tropical and subtropical thunderstorms and the importance of mesoscale convective systems, Atmos. Chem. Phys., 7, 2987-3013, doi:10.5194/acp-7-29872007, 2007.

Huntrieser, H., Schlager, H., Lichtenstern, M., Roiger, A., Stock, P., Minikin, A., Höller, H., Schmidt, K., Betz, H.-D., Allen, G., Viciani, S., Ulanovsky, A., Ravegnani, F., and Brunner, D.: $\mathrm{NO}_{\mathrm{X}}$ production by lightning in Hector: first airborne measurements during SCOUT-O3/ACTIVE, Atmos. Chem. Phys., 9, 83778412, doi:10.5194/acp-9-8377-2009, 2009.

Jensen, E. J., Toon, O. B., Selkirk, H. B., Spinhirne, J. D., and Schoeberl, M. R.: On the formation and persistence of subvisible cirrus clouds near the tropical tropopause, J. Geophys. Res., 101, 21361-21375, doi:10.1029/95JD03575, 1996.

Jensen, E. J., Pfister, L., Ackerman, A. S., Tabazadeh, A., and Toon, O. B.: A conceptual model of the dehydration of air due to freeze-drying by optically thin, laminar cirrus rising slowly across the tropical tropopause, J. Geophys. Res.-Atmos., 106, 17237-17252, 2001.

Jensen, E. J., Pfister, L., Bui, T. V., Lawson, P., Baker, B., Mo, Q., Baumgardner, D., Weinstock, E. M., Smith, J. B., Moyer, E. J., Hanisco, T. F., Sayres, D. S., Clair, J. M. St., Alexander, M. J., Toon, O. B., and Smith, J. A.: Formation of large $(\simeq 100 \mu \mathrm{m})$ ice crystals near the tropical tropopause, Atmos. Chem. Phys., 8, 1621-1633, doi:10.5194/acp-8-1621-2008, 2008.

Jensen, E. J., Lawson, P., Baker, B., Pilson, B., Mo, Q., Heymsfield, A. J., Bansemer, A., Bui, T. P., McGill, M., Hlavka, D., Heymsfield, G., Platnick, S., Arnold, G. T., and Tanelli, S.: On the importance of small ice crystals in tropical anvil cirrus, Atmos. Chem. Phys., 9, 5519-5537, doi:10.5194/acp-9-5519-2009, 2009.

Jensen, E. J., Pfister, L., Bui, T.-P., Lawson, P., and Baumgardner, D.: Ice nucleation and cloud microphysical properties in tropical tropopause layer cirrus, Atmos. Chem. Phys., 10, 1369-1384, doi:10.5194/acp-10-1369-2010, 2010.

Khaykin, S., Pommereau, J.-P., Korshunov, L., Yushkov, V., Nielsen, J., Larsen, N., Christensen, T., Garnier, A., Lukyanov, A., and Williams, E.: Hydration of the lower stratosphere by ice crystal geysers over land convective systems, Atmos. Chem. Phys., 9, 2275-2287, doi:10.5194/acp-9-2275-2009, 2009.

Khosrawi, F. and Konopka, P.: Enhanced particle formation and growth due to mixing processes in the tropopause region, Atmos. Environ., 37, 903-910, doi:10.1016/S1352-2310(02)00976-7, 2003. 
Korolev, A.: Reconstruction of the sizes of spherical particles from their shadow images. Part I: Theoretical considerations, J. Atmos. Ocean. Tech., 24, 376-389, 2007.

Korolev, A. V., Emery, E. F., Strapp, J. W., Cober, S. G., Isaac, G. A., Wasey, M., and Marcotte, D.: Small ice particles in tropospheric clouds: fact or artifact? Airborne Icing Instrumentation Evaluation Experiment, B. Am. Meteorol. Soc., 0, null, doi:10.1175/2010BAMS3141.1, in press, 2011.

Krämer, M., Schiller, C., Afchine, A., Bauer, R., Gensch, I., Mangold, A., Schlicht, S., Spelten, N., Sitnikov, N., Borrmann, S., de Reus, M., and Spichtinger, P.: Ice supersaturations and cirrus cloud crystal numbers, Atmos. Chem. Phys., 9, 3505-3522, doi:10.5194/acp-9-3505-2009, 2009.

Law, K. S., Fierli, F., Cairo, F., Schlager, H., Borrmann, S., Streibel, M., Real, E., Kunkel, D., Schiller, C., Ravegnani, F., Ulanovsky, A., D'Amato, F., Viciani, S., and Volk, C. M.: Air mass origins influencing TTL chemical composition over West Africa during 2006 summer monsoon, Atmos. Chem. Phys., 10, 10753-10770, doi:10.5194/acp-10-10753-2010, 2010.

Lawson, R. P.: Effects of ice particles shattering on optical cloud particle probes, Atmos. Meas. Tech. Discuss., 4, 939-968, doi:10.5194/amtd-4-939-2011, 2011.

Lawson, R. P., Pilson, B., Baker, B., Mo, Q., Jensen, E., Pfister, L., and Bui, P.: Aircraft measurements of microphysical properties of subvisible cirrus in the tropical tropopause layer, Atmos. Chem. Phys., 8, 1609-1620, doi:10.5194/acp-8-1609-2008, 2008.

Lee, S. H., Wilson, J. C., Baumgardner, D., Herman, R. L., Weinstock, E. M., LaFleur, B. G., Kok, G., Anderson, B., Lawson, P., Baker, B., Strawa, A., Pittman, J. V., Reeves, J. M., and Bui, T. P.: New particle formation observed in the tropical/subtropical cirrus clouds, J. Geophys. Res.-Atmos., 109, D20209, doi:10.1029/2004JD005033, 2004.

Liu, L. and Mishchenko, M. I.: Constraints on PSC particle microphysics derived from lidar observations, J. Quant. Spectrosc. Ra., 70, 817-831, 2001.

Luo, B. P., Peter, T., Fueglistaler, S., Wernli, H., Wirth, M., Kiemle, C., Flentje, H., Yushkov, V. A., Khattatov, V., Rudakov, V., Thomas, A., Borrmann, S., Toci, G., Mazzinghi, P., Beuermann, J., Schiller, C., Cairo, F., Di Donfrancesco, G., Adriani, A., Volk, C. M., Ström, J., Noone, K., Mitev, V., MacKenzie, R. A., Carslaw, K. S., Trautmann, T., Santacesaria, V., and Stefanutti, L.: Dehydration potential of ultrathin clouds at the tropical tropopause, Geophys. Res. Lett., 30, 1557, doi:10.1029/2002GL016737, 2003a.

Luo, B. P., Peter, Th., Wernli, H., Fueglistaler, S., Wirth, M., Kiemle, C., Flentje, H., Yushkov, V. A., Khattatov, V., Rudakov, V., Thomas, A., Borrmann, S., Toci, G., Mazzinghi, P., Beuermann, J., Schiller, C., Cairo, F., Di Don-Francesco, G., Adriani, A., Volk, C. M., Ström, J., Noone, K., Mitev, V., MacKenzie, R. A., Carslaw, K. S., Trautmann, T., Santacesaria, V., and Stefanutti, L.: Ultrathin Tropical Tropopause Clouds (UTTCs): II. Stabilization mechanisms, Atmos. Chem. Phys., 3, 1093-1100, doi:10.5194/acp-3-1093-2003, 2003b.

Massie, S., Gettelman, A., Randel, W., and Baumgardner, D.: Distribution of tropical cirrus in relation to convection, J. Geophys. Res.-Atmos., 107, 4591, doi:10.1029/2001JD001293, 2002.

McFarquhar, G. M. and Heymsfield, A. J.: Parameterization of Tropical Cirrus Ice Crystal Size Distributions and Implications for Radiative Transfer: Results from CEPEX, J. Atmos. Sci., 54, 2187-2200, doi:10.1175/15200469(1997)054;2187:POTCIC ¿2.0.CO;2, 1997.

McFarquhar, G. M. and Heymsfield, A. J.: The Definition and Significance of an Effective Radius for Ice Clouds, J. Atmos. Sci., 55, 2039-2052, 1998.

McFarquhar, G. M., Heymsfield, A. J., Spinhirne, J., and Hart, B.: Thin and subvisual tropopause tropical cirrus: Observations and radiative impacts, J. Atmos. Sci., 57, 1841-1853, 2000.

Park, S., Jiménez, R., Daube, B. C., Pfister, L., Conway, T. J., Gottlieb, E. W., Chow, V. Y., Curran, D. J., Matross, D. M., Bright, A., Atlas, E. L., Bui, T. P., Gao, R.-S., Twohy, C. H., and Wofsy, S. C.: The $\mathrm{CO}_{2}$ tracer clock for the Tropical Tropopause Layer, Atmos. Chem. Phys., 7, 3989-4000, doi:10.5194/acp-7-39892007, 2007.

Peter, Th., Luo, B. P., Wirth, M., Kiemle, C., Flentje, H., Yushkov, V. A., Khattatov, V., Rudakov, V., Thomas, A., Borrmann, S., Toci, G., Mazzinghi, P., Beuermann, J., Schiller, C., Cairo, F., Di Donfrancesco, G., Adriani, A., Volk, C. M., Ström, J., Noone, K., Mitev, V., MacKenzie, R. A., Carslaw, K. S., Trautmann, T., Santacesaria, V., and Stefanutti, L.: Ultrathin Tropical Tropopause Clouds (UTTCs): I. Cloud morphology and occurrence, Atmos. Chem. Phys., 3, 1083-1091, doi:10.5194/acp-3-1083-2003, 2003.

Pfister, L., Selkirk, H. B., Jensen, E. J., Schoeberl, M. R., Toon, O. B., Browell, E. V., Grant, W. B., Gary, B., Mahoney, M. J., Bui, T. V., and Hintsa, E.: Aircraft observations of thin cirrus clouds near the tropical tropopause, J. Geophys. Res.-Atmos., 106, 9765-9786, 2001.

Pommereau, J. P.: Troposphere-to-stratosphere transport in the tropics, CR Geosci., 342, 331-338, 2010.

Protat, A., Delanoë, J., Plana-Fattori, A., May, P. T., and O'Connor, E. J.: The statistical properties of tropical ice clouds generated by the West African and Australian monsoons, from ground-based radar-lidar observations, Q. J. Roy. Meteorol. Soc., 136, 345363, doi:10.1002/qj.490, 2010.

Real, E., Orlandi, E., Law, K. S., Fierli, F., Josset, D., Cairo, F., Schlager, H., Borrmann, S., Kunkel, D., Volk, C. M., McQuaid, J. B., Stewart, D. J., Lee, J., Lewis, A. C., Hopkins, J. R., Ravegnani, F., Ulanovski, A., and Liousse, C.: Cross-hemispheric transport of central African biomass burning pollutants: implications for downwind ozone production, Atmos. Chem. Phys., 10, 3027-3046, doi:10.5194/acp-10-3027-2010, 2010.

Sassen, K. and Cho, B. S.: Subvisual Thin Cirrus Lidar Dataset For Satellite Verification And Climatological Research, J. Appl. Meteorol., 31, 1275-1285, 1992.

Sassen, K., Wang, Z., and Liu, D.: Cirrus clouds and deep convection in the tropics: Insights from CALIPSO and CloudSat, J. Geophys. Res., 114, D00H06, doi:10.1029/2009JD011916, 2009.

Schiller, C., Krämer, M., Afchine, A., Spelten, N., and Sitnikov, N.: Ice water content of Arctic, midlatitude, and tropical cirrus, J. Geophys. Res., 113, D24208, doi:10.1029/2008JD010342, 2008.

Schumacher, C., Houze, R., and Kraucunas, I.: The tropical dynamical response to latent heating estimates derived from the TRMM precipitation radar, J. Atmos. Sci., 61, 1341-1358, 2004.

Schumann, U. and Huntrieser, H.: The global lightning-induced nitrogen oxides source, Atmos. Chem. Phys., 7, 3823-3907, doi:10.5194/acp-7-3823-2007, 2007. 
Seifert, M., Ström, J., Krejci, R., Minikin, A., Petzold, A., Gayet, J.-F., Schlager, H., Ziereis, H., Schumann, U., and Ovarlez, J.: Aerosol-cirrus interactions: a number based phenomenon at all?, Atmos. Chem. Phys., 4, 293-305, doi:10.5194/acp-4-293-2004, 2004.

Shur, G., Sitnikov, N., and Drynkov, A.: A mesoscale structure of meteorological fields in the tropopause layer and in the lower stratosphere over the southern tropics (Brazil), Russ. Meteorol. Hydrol., 32, 487-494, doi:10.3103/S106837390708002X, 2007.

Sitnikov, N. M., Yushkov, V. A., Afchine, A. A., Korshunov, L. I., Astakhov, V. I., Ulanovskii, A. E., Krämer, M., Mangold, A., Schiller, C., and Ravegnani, F.: The FLASH instrument for water vapor measurements on board the high-altitude airplane, Instrum. Exp. Tech., 50, 113-121, 2007.

Sokolov, L. and Lepuchov, B.: Protocol of interaction between Unit for Connection with Scientific Equipment (UCSE) and onboard scientific equipment of Geophysica aircraft (Second edition), Myasishchev Design Bureau (MDB), 1998.

Stewart, D. J., Taylor, C. M., Reeves, C. E., and McQuaid, J. B.: Biogenic nitrogen oxide emissions from soils: impact on NOx and ozone over west Africa during AMMA (African Monsoon Multidisciplinary Analysis): observational study, Atmos. Chem. Phys., 8, 2285-2297, doi:10.5194/acp-8-2285-2008, 2008.

Thomas, A., Borrmann, S., Kiemle, C., Cairo, F., Volk, M., Beuermann, J., Lepuchov, B., Santacesaria, V., Matthey, R., Rudakov, V., Yushkov, V., MacKenzie, A. R., and Stefanutti, L.: In situ measurements of background aerosol and subvisible cirrus in the tropical tropopause region, J. Geophys. Res., 107, 4763, doi:10.1029/2001JD001385, 2002.

Ulanovsky, A. E., Yushkov, V. A., Sitnikov, N. M., and Ravegnani, F.: The FOZAN-II fast-response chemiluminescent airborne ozone analyzer, Instrum. Exp. Tech., 44, 249-256, 2001.

Vaughan, G., Schiller, C., MacKenzie, A. R., Bower, K., Peter, T., Schlager, H., Harris, N. R. P., and May, P. T.: SCOUT03/ACTIVE - High-altitude aircraft measurements around deep tropical convection, B. Am. Meteorol. Soc., 89, 647-662, 2008.

Viciani, S., D'Amato, F., Mazzinghi, P., Castagnoli, F., Toci, G., and Werle, P.: A cryogenically operated laser diode spectrometer for airborne measurement of stratospheric trace gases, Appl. Phys. B-Lasers O., 90, 581-592, 2008.

Voigt, C., Schlager, H., Luo, B. P., Dörnbrack, A., Roiger, A., Stock, P., Curtius, J., Vössing, H., Borrmann, S., Davies, S., Konopka, P., Schiller, C., Shur, G., and Peter, T.: Nitric Acid Trihydrate (NAT) formation at low NAT supersaturation in Polar Stratospheric Clouds (PSCs), Atmos. Chem. Phys., 5, 13711380, doi:10.5194/acp-5-1371-2005, 2005.

Voigt, C., Kärcher, B., Schlager, H., Schiller, C., Krämer, M., de Reus, M., Vössing, H., Borrmann, S., and Mitev, V.: In-situ observations and modeling of small nitric acid-containing ice crystals, Atmos. Chem. Phys., 7, 3373-3383, doi:10.5194/acp7-3373-2007, 2007.

Voigt, C., Schlager, H., Roiger, A., Stenke, A., de Reus, M., Borrmann, S., Jensen, E., Schiller, C., Konopka, P., and Sitnikov, N.: Detection of reactive nitrogen containing particles in the tropopause region evidence for a tropical nitric acid trihydrate (NAT) belt, Atmos. Chem. Phys., 8, 7421-7430, doi:10.5194/acp-8-7421-2008, 2008.
Voigt, C., Schumann, U., Jurkat, T., Schäuble, D., Schlager, H., Petzold, A., Gayet, J.-F., Krämer, M., Schneider, J., Borrmann, S., Schmale, J., Jessberger, P., Hamburger, T., Lichtenstern, M., Scheibe, M., Gourbeyre, C., Meyer, J., Kübbeler, M., Frey, W., Kalesse, H., Butler, T., Lawrence, M. G., Holzäpfel, F., Arnold, F., Wendisch, M., Döpelheuer, A., Gottschaldt, K., Baumann, R., Zöger, M., Sölch, I., Rautenhaus, M., and Dörnbrack, A.: In-situ observations of young contrails - overview and selected results from the CONCERT campaign, Atmos. Chem. Phys., 10, 90399056, doi:10.5194/acp-10-9039-2010, 2010.

Volk, C. M., Riediger, O., Strunk, M., Schmidt, U., Ravegnani, F., and Ulanovsky, A. and Rudakov, V.: In situ tracer measurements in the tropical tropopause region during APE-THESEO, in: Stratospheric Ozone 1999, Proc. 5th European Workshop on Stratospheric Ozone, edited by: Harris, N. R. P., Guirlet, M., and Amanatidis, G. T., no. 73 in EUR19340, pp. 661-664, St. Jean de Luz, 2000.

Wang, P.-H., Minnis, P., McCormick, M. P., Kent, G. S., and Skeens, K. M.: A 6-year climatology of cloud occurrence frequency from Stratospheric Aerosol and Gas Experiment II observations (1985-1990), J. Geophys. Res., 101, 29407-29429, doi:10.1029/96JD01780, 1996.

Wang, P. K.: Moisture plumes above thunderstorm anvils and their contributions to cross-tropopause transport of water vapor in midlatitudes, J. Geophys. Res.-Atmos., 108, 4194, doi:10.1029/2002JD002581, 2003.

Weigel, R., Hermann, M., Curtius, J., Voigt, C., Walter, S., Böttger, T., Lepukhov, B., Belyaev, G., and Borrmann, S.: Experimental characterization of the COndensation PArticle counting System for high altitude aircraft-borne application, Atmos. Meas. Tech., 2, 243-258, doi:10.5194/amt-2-243-2009, 2009.

Weigel, R., Borrmann, S., Kazil, J., Minikin, A., Stohl, A., Wilson, J. C., Reeves, J. M., Kunkel, D., de Reus, M., Frey, W., Lovejoy, E. R., Volk, C. M., Viciani, S., D’ Amato, F., Cairo, F., Schlager, H., Law, K. S., Shur, G. N., Belyaev, G. V., and Curtius, J.: In situ observations of new particle formation in the tropical upper troposphere: the role of clouds and the nucleation mechanism, Atmos. Chem. Phys. Discuss., 11, 9249-9312, doi:10.5194/acpd11-9249-2011, 2011.

Winker, D. M. and Trepte, C. R.: Laminar cirrus observed near the tropical tropopause by LITE, Geophys. Res. Lett., 25, 33513354, 1998.

Yushkov, V., Oulanovsky, A., Lechenuk, N., Roudakov, I., Arshinov, K., Tikhonov, F., Stefanutti, L., Ravegnani, F., Bonafe, U., and Georgiadis, T.: A Chemiluminescent Analyzer for Stratospheric Measurements of the Ozone Concentration (FOZAN), J. Atmos. Ocean. Tech., 16, 1345-1350, doi:10.1175/15200426(1999)016;1345:ACAFSM ¿2.0.CO;2, 1999.

Zöger, M., Afchine, A., Eicke, N., Gerhards, M.-T., Klein, E., McKenna, D. S., Mörschel, U., Schmidt, U., Tan, V., Tuitjer, F., Woyke, T., and Schiller, C.: Fast in situ stratospheric hygrometers: A new family of balloon-borne and airborne Lyman- $\alpha$ photofragment fluorescence hygrometers, J. Geophys. Res., 104, 1807-1816, doi:10.1029/1998JD100025, 1999. 